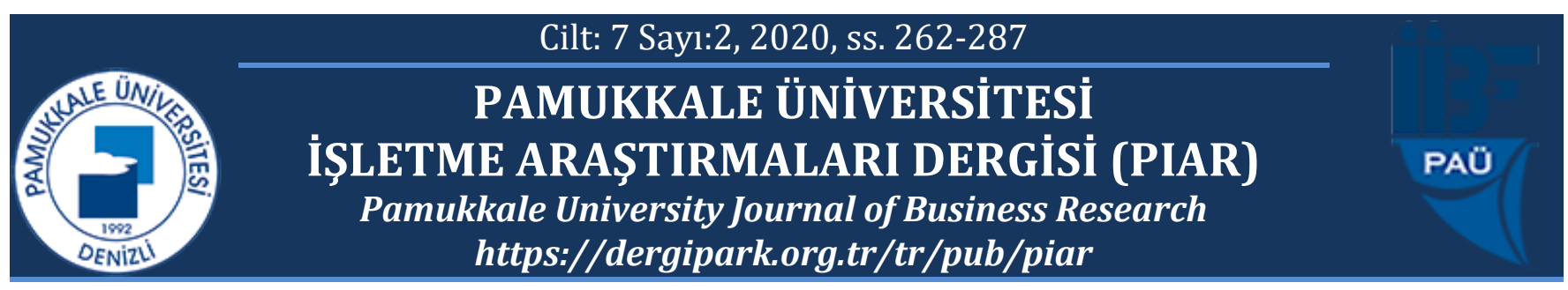

\title{
İmar Planlarının Yapılması, Değiştirilmesi ve Ortadan Kaldırılması Usulleri
}

\author{
Preparation, Amendment and Elimination Procedures of Zoning Plans
}

\section{Fikret Sami TIYYEK ${ }^{*}$}

\section{Yasin ULUSOY ${ }^{2}$}

Makale Geliş/Received: 09.11.2020

\section{Öz}

Imar planları, belirli bir alan veya bölge için yapılır. Bu planlar uzun vadeli ve geniş çaplı olabilirler. İleriye dönük olarak şehirleşmenin ve fiziki imkanların yüksek standartlarda oluşturulmasını amaçlar. Imar planları yapilırken, kamu menfaati, toplumun refahı ve gereksinimleri ön planda tutulmalıdır. Önemine binaen çalışmada en çok üzerinde durulan imar planları, nazım imar planlar ile uygulama imar planlarıdır. Imar Hukuku'nun temel kaynă̆ I Imar Kanunu olup, planların yapımı için hem mahalli idareler hem de Bakanlık yetkili kılınmıştır. Yetkili kuruma göre birtakım farklılıklar içeren imar planlaması faaliyeti, belirli ilkeler ve usuller çerçevesinde gerçekleştirilmelidir. İmar planlarının değiştirilmeleri, çok sık karşılaşılan bir durum olmamalıdır. Ancak mutlaka değiştirilmesi gerekiyorsa, kamunun ihtiyaçları gözetilerek yapılmalıdır. Imar planları, idarelerce kendiliğinden ya da menfaati olanların açacă̆ı iptal davası vasıtasıyla değiştirilebilir, iptal edilebilir.

Anahtar kelimeler: İmar Hukuku, Imar Planları, Imar Planlarının Yapılması Usulü, Imar Planlarının Değiştirilmesi ve İmar Planlarının Íptali Usulü

JEL kodlart: K30, K39
Makale Kabul/Accepted: 03.12.2020

\begin{abstract}
The zoning plans are made for a spesific area or region. These plans can be long-term and wide-ranging. It aims to achieve high standards of urbanization and physical facilities in the future. While the development plans are being made, public interest, needs and the welfare of the society should be prioritized. The most emphasized in the study are the development plans, master development plans and implementation plans. The main source of zoning law is code of reconstruction. Ministries and municipalities are authorized in making plans. Zoning planning differs according to the competent institution. Changing the zoning plans should not be a common situation. However, if it must be changed, it should be done considering the needs of public. The zoning plans can be changed or canceled by the administrations spontaneously or through the annulment action filed by those who have interest.
\end{abstract}

Keywords: Zonin g Law, Zoning Plans, Procedure for Preparation of Zoning Plans, Changing the Development Plans and Cancellation procedure of zoning plans

JEL codes: K30, K39 


\section{GİRIŞ}

İmar planı, belirli bir tarihsel oluşumun, zaman içinde geliştirdiği, fonksiyonlarda uzmanlaşmış bugünkü yerleşik alanlarda bunların çevresindeki gelişme alanlarının oluşturduğu, çeşitli alan kullanımları arasında en uygun kentsel gelişme biçimini belirleyen ve uygulamaya dönük ayrıntıda bir plandır (Yılmaz, 2012: 348-349; Keleş, 2015: 115). İmar ile yapı yoğunluğu, yerleşim alanlarının gelişimi, yapı adaları, ulaşım ağı, okul, ibadethane, hastane, yeşil alan gibi kamunun kullanımına ayrılan alanlar belirlenir.

İmar ve imar planı kavramına, ülkemizde duyulan ihtiyaç üzerine, anayasal bazda ilk defa 1982 tarihli Anayasa'nın 56. maddesinde yer verilmiştir. Sağlıklı bir çevrede yaşama hakkı kapsamında, idare, tüm imar planlamalarını yapmakla yükümlü kılınmıştır. Nitekim, idarenin düzenleyici işlemleri arasında yer alan imar planları, imar hukukunun da gelişmesine vesile olur.

İmar planlaması, araştırma ve analiz, hazırlanma, plan, uygulama, izleme ve değerlendirme aşamalarından oluştur (Kalabalık, 2014: 44; Yaşar, 2008: 11 vd.). Planlamanın amacı, sürdürülebilir kalkınmanın gerçekleştirilmesi, çevre, doğa, kültür ve doğal miras ile diğer alanların korunması olup, kamu ve toplum yararının gerçekleştirilmesini sağlayacak hukuki ortamın sağlanmasıdır. İmar Hukuku'nda planlar, temel mevzuat olan İmar Kanunu'na göre bölge planları ve imar planları olarak kapsanan alan ve amaca göre ikiye ayrılır. İmar planları kapsamına, nazım imar planları ve uygulama imar planları girer. Bunlar dışında, en üstte ülke kalkınma planı, bölge planları ve metropoliten imar planları vardır. Planlamada yetkili makamlar, mahalli idareler ile Bakanlık ve diğer yetkili kurumlardır. Bu kurumlar tarafından yapılmış planlar hakkında yargıya başvurulması halinde, yerel idare mahkemeleriyle Danıştay yetkilidir.

Çalışmamızın konusu imar planlarının yapılması, değiştirilmesi ve ortadan kaldırılması usulleridir. Buna paralel olarak üç ayrı bölüm bulunmaktadır. İlk bölümde genel olarak imar planlarının yapım öncesi çalışmalar ve yapımı anlatılacak olup, planların onaylanması ve yürürlüğe girmesi işlenecektir. Çalışmanın ikinci bölümünde imar planlarının değişiklik usulleri detaylıca incelenecek ve planların değiştirilmesinde kimlerin söz sahibi olduğu hususu irdelenecektir. Son bölümde ise planların ortadan kaldırılması usulleri yargı kararları çerçevesinde değerlendirilecektir.

\section{IMAR PLANLARININ YAPILMASI}

\section{1. İmar Hukukunda Planlama}

İmar Hukuku, genç ve dinamik bir alan olarak, kanun bazında köklü bir geçmişe sahip değildir. Ancak, idare hukuku başta olmak üzere, şehircilik ilkeleri ve imar uygulamaları da değerlendirildiğinde, plan yapımına ilişkin sahip olunan tecrübeler yol göstericidir. $\mathrm{Bu}$ çerçevede, öncelikle açılanması gereken kavram, plânlamadır. Plânlama kavramı, içinde bulunulan yahut belirlenebilir bir andan sonrasında yaşanacaklar için hakkında fikir beyan edilen, tasarlama yapılan bir düşünce şekli, insanların yaşadığı veya bulunduğu bölgede düzenli ilişkilerin kurulmasını sağlamaya yarayan çeşitli hazırlık faaliyetleri olarak tanımlanabilir (Kalabalık, 2014: 43).

İdarenin bir fonksiyonu konumunda bulunan planlama, önceden saptanmış hedeflere, yine önceden belirlenmiş sürelerde ulaşılması için izlenmesi gereken yön ve yöntemleri belirleme 
faaliyeti olarak tanımlanmaktadır (Kalabalık, 2014: 43). Çalışma konumuz olan imar planlarının yapılması, değiştirilmesi gibi faaliyetlerde esas alınacak temel kanun, 3194 sayılı İmar Kanunu'dur (RG., 9.5.1985, Sa., 18749). İmar Kanunu'na göre planlar, üst ölçekten alt ölçeğe göre doğru hiyerarşik bir düzen içindedir. Bir üst ölçekteki plan, kendisinden sonra gelen alt ölçekli planın temellerini teşkil etmektedir. Plan hiyerarşisine bakıldığında, esas nokta, plan kararlarının devamlılığı ve bütünlüğünü sağlamak amacıyla her planın bir üst ölçekteki plana uyumlu olmasıdır.

3194 sayılı Kanun'un "Mekânsal Planlama Kademeleri” başlı̆̆ını taşıyan 6. maddesinde, planlar, kapsadıkları alan ve amaç açısından çevre düzeni planları ile imar planları olarak iki ana gruba ayrılmış ve imar planlarının, nazım imar planlarıyla uygulama imar planlarından oluştuğu ifade edilmiştir. Anılan Kanun'un 8. maddesinin b bendinde de açık bir biçimde, İmar planlarının; uygulama imar planı ile nazım imar planından oluşacağı ifade edilerek bu iki plan türü tanımlanmıştır. Aynı Kanun'un 5. maddesinde nazım imar planı açıklanırken, bu planın varsa bölge ve çevre düzeni planlarıyla uyumlu biçimde hazırlanmaları gerekeceğine işaret edilmiştir. Uygulama imar planının da "nazım imar planın esaslarına göre" yapılacağ öngörülmektedir. Aynı maddede çevre düzeni planı tanımlanırken, mevcutsa mekânsal strateji planlarıyla bağlantılı bir biçimde bölge, havza ya da il bazında düzenlenen planlardan bahsedilmektedir ${ }^{1}$.

İmar planları kavramı, 3194 sayılı Kanun'un 8.maddesinin b fıkrasında tanımlanmıştır. Buna göre, varsa, çevre düzeni ile bölge planlarına ilişkin kararlara paralel bir biçimde belediye ve mücavir alan sınırlarındaki planları yapma/yaptırma yetkisi ilgili belediyelerde; söz konusu yasanın yine aynı maddesine göre belediye ile mücavir alanlar dışındaki bölgelerde yapılacak planları yapma/yaptırma yetkisi ise valiliklerde veya ilgililerinde bulunmaktadır. Ancak, İmar Kanunu'nun İstisnalar başlıklı 4. maddesinde; Turizmi Teşvik Kanunu, Kültür ve Tabiat Varlıklarını Koruma Kanunu ile İmar Kanunu'nun ilgili maddelerine uygun olmak şartıyla İstanbul Boğaziçi Kanunu ve Büyükşehir Belediyelerinin Yönetimi Hakkında Kanun ile diğer özel kanunlar ile belirlenmiş ya da daha sonra yapılacak belirme için İmar Kanunu hükümleri, özel kanunlarda yer alan hükümlere aykırı olmadığı ölçüde uygulanabilecektir. $\mathrm{Bu}$ itibarla, imara ilişkin karar alma ve uygulama gibi birçok konuda, yerel yönetimler dışında çeşitli merkezi kurum ve kuruluş da yetkili hale getirilmiştir. Yine, İmar Kanunu'nun 9. maddesinde Çevre ve Şehircilik Bakanlığı'na, "gerekli görülen hallerde" arazi kullanımına ve yer seçimine karar verme, planların onanması ve uygulanması yetkileri verilmiş; esasında tek bir mercii tarafından yönetilmesi/uygulanması daha uygun olabilecek imar planlarının imar planlarının yapımı ve değiştirilmesi usullerine dair birçok farklılığın mevcudiyetine sebep olunmuştur. Bu noktada çeşitli yetki gaspları ortaya çıkabilmekte, mahkemelerce iptal kararları verilebilmektedir. Örneğin, PTT'nin bir bölge müdürlüğünce hazırlanan mevzi imar planını onayan belediye meclisi kararının iptali istemiyle açılan

'Bununla birlikte İmar Kanunu'nun, imar planlarında Çevre ve Şehircilik Bakanlığı'nın yetkisini düzenleyen 9. maddesi, birden fazla belediyeyi ilgilendiren metropoliten imar planlarına yer vermektedir (Bal, 2010: 57). Bunlara ek olarak, İmar Kanunu ve Mekansal Planlar Yapım Yönetmeliği'nde ve diğer kanunlarda "Mekansal Plan”, "Kentsel Tasarım Projesi”, “Mekansal Strateji Planı", "Çevre Düzeni Planı”, “Eylem Planı”, "İmar Planı Revizyonu”, “Koruma Amaçlı İmar Planı”, “Mekansal Strateji Planı”, “Uzun Devreli Gelişme Planı” ve “Ulaşım Ana Planı" gibi tamamlayıcı ve özel amaçlı plan tanımları bulunmaktadır (Genç, 2015: 23-24; Demir, 2009: 11). 
davada Danıştay, yasaya aykırılık bulunduğuna hükmetmiştir (Danıştay 6. Daire, T. 29.3.1989, E.1988/266, K.1989/714).

\section{2. İmar Planlarının Yapılma Süreci}

\subsubsection{Planlamanın Aşamaları}

Planlama, bütüncül bir süreçtir ve bu sürecin başlaması, ihtiyaçların ve nihai hedefin belirlenmesi, ortaya çıkabilecek sorunların saptanması, ve çeşitli seçeneklerin değerlendirilip test edilerek, muhtemel sonuçların göz önüne alınarak ve önceden saptanan hedefler doğrultusunda seçimler yapılırken oluşabilecek tüm yeni durumların ve değiş̧kenlerin tekrar değerlendirilerek, gerekirse başlangıçtaki hedeflerin yeniden düzenlenmesi ve uygulamanın bu doğrultuda devam etmesiyle gerçekleştirilir (Ergen, 2006: 18). İmar planlaması, büyüme eğiliminde olan bölgelerin denetim altında tutularak, büyümenin kontrollü bir şekilde sağlanmasını amaç edinmektedir. Planlamacılar ve yöneticiler, belirli bir yerleşim yerinde, nüfus artışını kontrol ederek yaşam standartlarının yükseltilmesi amacıyla işlev görmektedirler. Bu doğrultuda, kentlerin gelişmesinde ve imarında hukuk kurallarına riayet edilmesinin çeşitli açılardan birçok faydası vardır (Öz, 2011: 7). Burada planlama öncesi hazırlık işlemlerinin yapılması ve bir kentin tüm unsurlarıyla birlikte planlama faaliyetine hazır hale getirilmesinin önemine vurgu yapmakta fayda bulunmaktadır. Yine, planlama, gelecek nesillere daha düzenli ve sistemli bir ülke bırakılarak, refah seviyesinin üst seviyede tutulması amacıyla daha kalıcı ve uzun vadeli yapılmalıdır. Nitekim, yargı kararlarında da bu unsurlara işaret edilmektedir. Örneğin, Danıştay 6. Daire'nin 2011 tarihli E.: 2010/8460, K.:2011/335 sayılı kararında (bkz.: Genç, 2015: 29) hazırlık aşamasında yapılan bir uygulama olan Çevresel Etki Değerlendirme (ÇED) Raporunun çevre düzeni planlarıyla birlikte değerlendirilerek ilgili bölgede planlama yapılması gerektiğine ilişkin olarak şu değerlendirme yapılabilir: İmar planlarının, ilgili bölgenin güncel durumunun, olanakları ve gelişiminin en doğru biçimde belirlenebilmesi adına coğrafi bilgileri, bölgenin kullanımına ilişkin tüm veriler ışığında, gerekirse anket ve diğer çalışmalarla farklı olanakların bir arada değerlendirilmesi suretiyle en optimal çözümün bulunarak gerçekleştirilmesi gerekir. Bu doğrultuda, o bölgede yaşayan insanlar için refah seviyesinin yukarıya çıkartılarak iyi yaşam şartlarının oluşturulması amacıyla o bölgeye özel olarak tespit edilecek yaşam standartlarıyla nüfus ilişkilerinin ve çevresindeki yerleşim alanlarıyla ilişkinin korunarak bunlara uygun bir biçimde sosyal ve kültürel olanakların korunması; sağlık ve güvenlik başta olmak üzere tüm boyutlarıyla ele alınması ve uzun vadeli hazırlanması elzemdir. $\mathrm{Bu}$ açılamalardan da anlaşılacağı üzere, gerek planlama öncesi aşamalar gerekse planın elde etme şeklinin belirlenmesi ve planın yapılması aşamaları, plan kararlarına geçişte büyük önem arz etmektedir.

İmar planlarının hazırlık aşamalarında, planın yapılması için bazı kurumlara başvuru yapılması, belediye başkanına yetki verilmesi gibi durumlarda, henüz yapılmış, onaylanmış ve ilan edilmiş bir plan da bulunmayacağı için, bu planların ileride görülecek olan iptal davasına konu edilmesi de mümkün olmayacaktır (Danıştay 6. Daire, T. 5.2.1992, E. 1991/3328, K. 1992/476). Burada son olarak, imar mevzuatına göre herhangi bir taşınmazın imar planında öngörüldüğü amaç dışında kullanılmak üzere yapılaşamayacağına işaret edilmesi gerekmektedir (Danıştay 6. Daire, T. 7.5.2010, E. 2008/5038, K. 2010/4664). 


\subsubsection{Halihazır Harita Alımı}

İdari işlemler, yapılmalarından önce var olan ve üst normlarla belirlenmiş sebeplere dayanmak zorundadırlar. Bu itibarla, bir idari işlemin sebebini, idareyi o işlemi yapmaya sevk eden nesnel hukuk kurallarınca belirlenmiş bulunan etkenler oluşturur ve o idari işlemden önce gelirler (Günday, 2003: 138). Çeşitli hazırlık işlemlerinin yapılmasından sonra bir rapor ortaya çıkar ve bu sayede imar planları karara bağlanır. Hazırlık çalışmaları, raporla birlikte imar planlarının sebep unsurunu oluştururlar. Yerel planlamaya temel olmak üzere toplanan bilgiler, harita, şema ve grafikler olarak, kolay takip edilecek şekilde karar verecek idarî makamların ilgili organlarının önüne getirilir (Kalabalık, 2014: 93).

Hâlihazır haritalar, plan çalışmalarına dayanak olan ve ilgili arazinin o dönemki kullanılış şeklini, yani o andaki caddeleri, kamuya ait binaları, diğer binaları ve topografik durumu gösterirler (Kalabalık, 2014: 93; Yayla, 2010: 34). Esas itibariyle yapıldığı bölgeye ait alanların değerlendirme biçimleri hakkında bilgi veren grafik gösterimi (Çolak, 2010: 186) olmakla beraber ticaret ve konut alanları, kaldırımlar, kamu binalar ile diğer yeşil alanlar, arsa değerleri, kat adetleri, nüfusa ilişkin bilgiler ile kentin ulaşım ağıyla ilgili çeşitli bilgileri barındıran, altyapı hakkındaki yerleşimi gösteren bir başka ifadeyle güncel durumu (Kalabalık, 2014: 93) gösteren haritalardır. Halihazır kelimesinin kelime anlamıla da uyuşacak şekilde, güncel durumu gösteriyor olmaları, gösterdiği bölgenin gözle görülebilen o anki durumunu; arazinin kullanılış biçimini, gölleri, nehirleri, tepeden bakıldığından görülebilecek karayolları, demiryolları gibi insan yapımı yapılar ve tesislerin yapay bir biçimde gösterilmesi (Kalabalık, 2014: 93-94; Yıldız, 2012: 112) anlamına gelir. Halihazır haritaların taşıdıkları önem, imar planlarının yapımında esas alınmaları ve imar planlarının bu haritaların üzerine yapılmasıdır.

Halihazır harita ve plan raporu, İmar Kanunu'nun 5. maddesinde gösterilen imar planlarının yapılabilmesi için gereken planın temelini oluşturur ve aydınlatıcı bir işlev görürler. Yine, planın bir parçası olan plan notları da plan kararı oluşturan asıl iradenin (Bal, 2010: 60) oluşumuna katkı sağlayan hazırlayıcı, açıklayıcı işlemlerdir. Bir başka ifadeyle, planların hazırlık sürecinde yapılacak araştırma, inceleme ve bilgi toplama faaliyetleri sonrasında, bu çalışmaların bilimsel yöntemlerden faydalanılmak suretiyle raporlandırılması son derece elzemdir (Çolak, 2010: 185). Halihazır haritaların yapılmasında uyulacak esaslar, İmar Kanunu'nun 7. maddesinin (a) bendinde, halihazır haritası bulunmayan yerleşim yerlerinin haritalarının belediye ya da valilik tarafından yapılacağı/yaptırılacağı ifade edilmiştir. Bu haritalar, belediye ve valiliklerce onaylanır ve bir örneği Çevre ve Şehircilik Bakanlığı'na, bir örneği de ilgili tapu dairesine gönderilir. Belediye ve mücavir alan sınırlarındaki halihazır haritalar, belediyelerin teknik personelince ya da emanet usulüyle yapılabileceği gibi, İlbank'a yetki verilerek ya da harita mühendislerine ihale edilerek yapılabilir (Kalabalık, 2014: 95). Belediye ve mücavir alan sınırları dışındaki alanlarda ise halihazır harita, valinin onayıyla yürürlüğe girer (Kalabalık, 2014: 96).

\subsubsection{2. İlgili Kurum ve Kuruluşlardan Rapor ve Görüş Alınması}

Mekansal Planlar Yönetmeliği'nin (RG.: 14.6.2014, Sa.: 29030) 21. maddesinin üçüncü fıkrasına göre, halihazır haritaların alınması ve ilgililerince onaylandıktan sonra planlama aşamasına geçilebilmesi, planlara yönelik olarak doğal varlıkların tespiti ve korunması gibi verilerin elde edilmesine bağlıdır. Bu sebeple imar planlarının yapılmasından önce çeşitli 
inceleme, araştırma ve analiz çalışmalarının yapılması gerekir. İşte bu çalışma ve etütlerin değerlendirilmesi sonucunda ortaya çıkan sentez, planların yapımına esas teşkil eder. İmar Kanunu'nun 8. maddesinin (e) bendine göre, plana ilişkin olarak ilgili kamu kurum veya kuruluşlarının ya da planın müelliflerinin, kamu kurum ve kuruluşlarının görüşlerini istemesi ve bunların da en geç 30 gün içerisinde görüşlerini bildirmesi gerekir. Görüş bildirilmesi amacıyla uzun süreli çalışma yapılması gerekiyorsa, 30 günü geçmeyecek şekilde ek süre verilebilir. Bu sürede de görüş bildirilmezse, planın zımnen kabul edildiği, herhangi bir itirazın bulunmadığı kabul edilir.

\subsubsection{Eşik Analizi}

Mekansal Planlar Yapım Yönetmeliği'nin 22. maddesinin üçüncü fıkrasına göre, plan kararlarının oluşturulması aşamasında temel plan altlı̆gı olarak kullanılmak üzere eşik analizlerinin yapılması, imar planının hazırlanabilmesi için şarttır. Planların hazırlanması aşamasında, yerleşilebilir bölgelerin belirlenmesi için toplanan tüm bilgilerin, o bölgeye özel olarak yapılan etütler ve diğer verilerle değerlendirilerek ihtiyaç bulunan ölçülerde halihazır haritalarla eşleştirilir ve eşik analizleri hazırlanır. Yapılan bu analizlerde tüm yapısal özellikler (jeolojik, topografik vb.) ve arazinin kullanımına ilişkin veriler, tarım ve orman alanları, içme suyu havzaları, sit ve diğer koruma alanlarıyla hassas bölgeler, kıyılar, altyapıya ve doğal ve fiziki verilere ilişkin bilgiler ile afet tehlikeleri analiz edilerek bir arada değerlendirilmek suretiyle planlama faaliyetinde önemli bir işlevi yerine getirir (Kalabalık, 2014: 99). Planlamada eşik analizi (treshold analysis) yapılarak, ucuz altyapı maliyetleri ile gelişebilir alanlar tespit edilmekte ve bu alanlar planlanarak, yerleşim alanlarının düzenlenmesi ve kentsel gelişmenin bu alan içinde kalması amaçlanmaktadır (Tunçer).

\subsubsection{Planın Elde Etme Şeklinin Belirlenmesi ve Plan Yaptırma Yolları}

Yukarıda ifade ettiğimiz tüm çalışmalar sonucunda elde edilmiş verilerin ve bilgilerin değerlendirilip ne tür bir yol haritası izleneceği, plan yapım sürecinde hangi kurumların rol alacağı hususunda bir belirleme yapıldıktan sonra planların emanet usulü, ihale usulü yahut yarışma usullerinden hangisinden faydalanılacağı belirlenir.

İmar hukukuna ilişkin planların yapım usulleri ve değiştirilme şekilleri, kurallarla belirlenmiş ve üzerlerinde yorum yapılmasına mahal vermeyecek türdendir. Nitekim, idare bütünü içinde yer alan bütün kurumların imar planlarını yapma ve değiştirme yetkisi bulunmamaktadır. İmar planlarını, sadece yetkili idarî makamlar yapar ve değiştirebilir. İmar planlarının yapılması ve değiştirilmesi konusunda başvurulması gereken ilk norm, İmar Kanunu hükümleridir. Anılan Kanun'un 7. ve 8. maddelerine göre, imar planlamasında asıl yetki mahalli idarelerde olup, belediyeler, geniş yetkilerle donatılmıştır (Yıldız, 2012: 125). Yine valilikler de bu kapsamda yetkilendirilmişlerdir. Bir diğer mahalli idare olan il özel idareleri de imar planlarının yapılması ve değiştirilmesinde yetki sahibidir (Kara, 2016: 73-74). İmar planları, planları yapmakla görevli olan kurumlar tarafından re'sen, kendi bünyelerinde kurulacak özel bir planlama grubu tarafından yapılır. Planların bu şekilde yapılması halinde, planlama grubu içinden en az bir kişinin Plan Yapımını Yükümlenecek Müelliflerin Yeterliliği Hakkında Yönetmelik (RG.: 7.1.2006, Sa.: 26046) kapsamında belirlenen niteliklere sahip olması aranmaktadır (İmar planı yapılırken bir müellifin görüşünün alınması gerektiğine ilişkin bkz.: Danıştay 6. Daire, T. 18.6.1992, E.1991/1613, K.1992/2948: Kalabalık, 2014: 100-101). Bu bağlamda, imar planlarının, ilgili hukukî normlar 
dikkate alınarak, yeterliliği haiz müelliflerce, tüm teknik boyutlarının değerlendirilerek hazırlanmaları zorunlu tutulmuştur (Danıştay 6.Daire, T.28.3.2001, E.2000/907, K.2001/1620) (MPYY m. 21, IV). Hatta, plan müelliflerinin imar planı değişikliklerini dava edebileceklerine ilişkin karar için bkz.: Danıştay 6. Daire, T.14.1.2004, E.2003/5595, K.2004/179 (Canbazoğlu ve Ayaydin, 2011: 263) ${ }^{2}$.

İmar planları, planları yaptıracak olan ilgili idareler tarafından, doğrudan doğruya ihale usulüyle yahut İlbank'a yetki verilerek bu kurum tarafından ihaleye çıkılarak da gerçekleştirilebilir ${ }^{3}$. Yine, yeterlilik belgesine sahip plancılara da nazım ve uygulama imar planlarıyla ilgili değişiklikleri yapma yetkisi doğrudan verilebilir (Kalabalık, 2014: 101). Özellikle plan müellifi ve diğer teknik elemanların yetersizliğinin söz konusu olabileceği belediyelerde imar planlarının, bu konularda daha deneyimli bir kurum olan İlbank'a yaptırılmasının uygun olacağı ifade edilmiştir (Ergen, 2006: 340). Yine, nispeten hızlı gelişen ve bunun sonucu olarak da hem toplumsal hem de ekonomik anlamda çeşitli sorunların baş gösterdiği bölgelerde, belediyeler adına İlbank tarafından tasarım yarışmaları yapılması önerilmektedir (Kalabalık, 2014: 101). Uygulamada, belediyelerin, plan yapma yetkilerini İlbank'a devretmekte çekingen olmadıkları ve koruma amaçlı imar planlarının istisnai olarak yarışma usulüyle, diğer planların çoğunlukla ihale usulüyle yapıldığ 1 ifade edilmiştir (Yıldız, 2012: 126).

\subsubsection{Plan Kararları}

İmar planlama çalışmalarında elde edilen veriler, analiz edilerek bilimsel sonuçlara dönüştürüldükten sonra karar aşamasına gelinir. Başka bir ifadeyle, ham halde, hazırlık aşamasındaki bilgilerle veriler analiz edilir (Çolak, 2010: 192). Hazırlık aşamalarında yapılan araştırmalar, plan kararlarının oluşturulmasında esas alınır. İmar planlarının bilimsel esaslara dayalı çalışmaların ürünü olarak elde edilen verilerin analiz edilmesi ve genel planlama ilkelerine uygun bir biçimde o günkü şartlar gözetilerek oluşturulan dengelerin sayesinde, planlar maddi-hukuki bir kimliğe sahip olurlar (Çolak, 2010: 192). Plan kararları, inceleme ve araştırma sonuçlarına dayanılarak oluşturulduklarından, plan raporlarında, yapılan inceleme ve araştırmalar, değerlendirmeler, planların gerçekleştirilmesini sağlayacak uygulama araçlarıyla kurumsal yapı ve denetim konularındaki kurallar bulunur (Kalabalık, 2014: 114-116). Somut bir planın ortaya konulabilmesi için, toplanmış olan verilerle hedeflerin birbirini tutması da gerekir. Nitekim, teknik açıdan yapılan değerlendirmeler son bulduğundan, planların karara bağlanması aşamasına geçilecek ve artık idari prosedürler ele alınacaktır (Çolak, 2010: 193).

\footnotetext{
${ }^{2}$ Burada, dikkat çekilmesi gereken nokta, İmar Kanunu'nun 8. maddesinde yer alan ve belediye sınırları içinde bulunan yerlere ait nazım ve uygulama imar planlarının, ilgili belediye tarafından yapılacağı/yaptırılacağı ve belediye meclisi tarafından onaylandıktan sonra yürürlüğe gireceğinin düzenlenmesine rağmen, belediyenin hangi organlarınca yapılacağının açıkça belirlenmediğidir. Doktrinde bu durum, planların yapılması hususunun esas olduğu ve kim yahut kimler tarafından yapıldı̆̆ı yerine, hangi merci tarafından onaylanacağının belirlenmiş olmasının yeterli olduğu şeklinde yorumlanmıştır (Kalabalık, 2014: 103).

3Iller Bankası Anonim Şirketi Hakkında Kanun'un (RG.: 8.2.2011, Sa.: 27840) 3. ve 4. maddelerine göre, il özel idareleri ve belediyeler, Banka'nın ortaklarıdır ve bunların tüm finansman giderleri Banka (bundan sonra metin içinde İlbank olarak anılacaktır) tarafından karşılanır (Kalabalık, 2014: 102). Yine, İlbank, bu idareler yetkisi içinde bulunan bölgelerde yaşayanlara sunulacak ortak hizmetlerin yapımı ve devamı aşamalarında, proje geliştirme, danışmanlık yapma, teknik anlamda projeler ve alt/üst yapı işlerinin yapımında destek olarak kalkınma ve yatırım bankacılığı işlevini görür (İller Bankası K. m.3).
} 


\subsection{2. İmar Planlarının Yapılması}

\subsubsection{Genel Planlama Esaslanı}

Planlama süreci, gerekli araştırmaların yapılarak, varsa mevcut sorunların tespiti, bilgi ve veri toplanmasıyla alakalı analiz aşaması, toplanan verilerin ve bilgilerin birleştirilerek sonuçların topluca değerlendirilmesi için yapılan sentez faaliyetiyle plan kararlarının alınması evrelerinden oluşur. Mekansal Planlar Yapım Yönetmeliği'nin 7. maddesinde genel planlama esaslarına yer verilmiştir. Buna göre, her tür ve ölçekteki mekânsal planların hazırlanmasında, belirli ilke ve kurallarla standartlara uygunluğun sağlanması gereklidir. Bu yapılırken, tanımlarla gösterim teknikleri de dikkate alınmalı ve başta kamu yararı olmak üzere çeşitli esaslar gözetilir. Danıştay 6. Dairesi'nin 2013/5536 E., 2014/2440 K. sayılı ve 28.3.2014 tarihli kararında şehircilik ve planlama ilkeleri gözetilmeden ve konut adası içinde konut işleviyle tampon bölge oluşturulmadan uyuşmazlığa konu taşınmaza, mevcut imar planında konut parselleri arasında plan bütünlüğ̈ gözönüne alınmadan bir yapı yapılmasının, kamu yararına aykırı olduğundan bahisle, iptal kararı verilmiştir. Genel planlama esaslarına şunlar örnek olarak gösterilebilir:

-Planların yapılmasında diğer planların küçültülmesi yahut detaylandırılması gibi yöntemler izlenemez- Planları oluşturan unsurlar; gösterim, pafta, plan notlarıla plan raporudurPlanlar, belirli kıstasları korumak kaydıyla bir alt kademede yer alan planlara yön verir- Alt kademede yer alan planlar bağlamında yol gösterici olacak üst kademe planları, yol haritası niteliğindedir- Mekânsal strateji planları, çevre düzeni planları ile nazım imar planları üzerinden ölçü alınarak uygulama yapılamaz- Planların yapımında, kültürel ve sosyal değerler korunarak, topografik veriler esas alınır ve mevcut olan doku korunmaya çalışılırPlanlar yapılırken tüm paydaşların mümkünse bilgilendirilmesi ve onaylarının alınarak saha araştırmalarının yapılması ve görüş toplama faaliyetinin atlanmamasına özen gösterilmelidir- Planlar iptal edilirse, önceden toplanmış kişi ve kurum görüşleriyle diğer veriler, yeni plan yapımında dikkate alınır.

\subsubsection{2. İmar Planı İlkeleri}

Mekansal Planlar Yapım Yönetmeliği'nin 21. maddesinde imar planlarının yapımında uyulacak ilkeler gösterilmiştir. Buna göre: İmar planları, mevcutsa kadastrosu yapılmış ve son onayı verilmiş halihazır haritalar üstüne çizilerek hazırlanır. Kıyı bölgelerde yapılacak olan planlarda, onaylanmış kıyı kenar çizgisi, paftanın üzerinde gösterilir. Gerekli görülürse, uygulama ve nazım imar planı, birlikte çizilebilir. Ancak, uygulama imar planının onaylanabilmesi için, nazım imar planının kesinlik kazanmış olması aranır. Yine hazırlanmada olduğu gibi, bu plan türlerini onaylama yetkisi aynı idaredeyse, onaylama işlemi de birlikte yapılabilir. İmar planları, planlama alanına ilişkin inceleme, araştırma, etüt ve eşik analizi çalışmalarıyla varılan değerlendirme sonuçlara göre hazırlanır.

Yukarıda da ifade ettiğimiz gibi, imar planlarının, yeterliliği haiz müelliflerce ilgili mevzuata uygun bir biçimde tüm hazırlık aşamalarının tamamlanarak hazırlanması şarttır. Bu Yönetmelikte yer alan hükümlere uygun bir biçimde hazırlanmış planlar ve bu planlar üzerinde yapılacak tüm değişiklik teklifleri, onaylanmak üzere ilgili idareye sunulur. Mevzuatın öngördüğü şekilde onaylanmış bulunan jeoteknik - jeolojik yahut mikro bölgeleme etüt raporlarının bulunmadığı bölgelerde, plan hazırlanması mümkün değildir. 
Bu raporların öngördüğü yerleşim planlarına uyulması ve bu raporlar yoksa, önceki etütler ve raporların kullanılması gerekir. Çevre kirliliğine sebep olmayacak sosyal alanların ilk olarak kamu mülkiyetinde bulunan alanlarda planlanması gerekmektedir. Yine, insan ve doğaya zararlı olabilecek yüksek gerilim hatları, taşma riski bulunan alanlar, afet bölgeleri ve benzeri yerlere ilişkin ilgili kamu kurumlarından alınacak görüşler, imar planının yapımında dikkate alınır. Konut kullanımının yapılacağı alanlardaki imar planlarında, bunlara ait oranların belirtilmesi, buna göre ayrılacak sosyal ve altyapı olanaklarının belirlenmesi için şarttır. Karma kullanım alanlarında, belirtilmemişse, konut kullanımı oranı, en yüksek yüzde 30 oranındadır.

İmar planları yapılırken, çevresel tüm etkenlerle birlikte, trafik yoğunluğunun azaltılarak (araç otoparklarının yapılması vb.), toplu ulaşım araçlarının kullanımının artırılmasına teşvik edilmesine azami dikkat gösterilmelidir. Yine, bu bağlamda afet gibi acil durum hallerinde ihtiyaç duyulabilecek tüm olanakların (yol vb.) gözden geçirilmesi ve buna uygunluğun sağlanması elzemdir.

\subsubsection{Nazım İmar Planlarının Yapılması}

Nazım imar planları, halihazır haritalar üzerine, mevcutsa bölge veya çevre düzeni planlarına uygun bir biçimde hazırlanır. Bu planlarda, ilgili arazilerin genel kullanım şekline, bölge tipine, olası nüfus artışı halinde nüfus ve yapı yoğunluğuna uygun bir düzenleme yapılması gerekir. Yine, yerleşim bölgelerinin gelişecekleri yöne göre belirlenecek ilkelerle ulaşım ağlarını ve olası sorunların çözümüne ilişkin hususları içerir ve uygulama imar planlarına temel teşkil eder. Büyükşehir olmayan yerlerde $1 / 5000$ 'e kadar ve kadastral durumu içerecek şekilde, büyükşehir belediyesi sınırlarında 1/5000 ile 1/25000 arasındaki ölçeklerde, detaylı bir raporu ihtiva edecek şekilde ve bu raporla bir bütün olacak planlar, nazım imar planlarıdır (İK m. 5/I; MPYY m. 4/i) (Genç, 2015: 34). Kent yerleşiminin sağlıklı, düzenli ve estetik bir biçimde kurulabilmesini temin amacıyla hazırlanan nazım imar planları, yerleşim, sanayi, ticaret bölgeleriyle yeşil alanlar, oturum dışı bölgeler ve ulaşım ağının planlanması işlevini yerine getirir (Çolak, 2010:136).

Nazım imar planı olarak adlandırılmasa da, nazım imar planında bulunması gereken tüm niteliklere haiz olan planlar, nazım imar planı olarak adlandırılabilir (Kalabalık, 2014: 106). Örneğin, insanların neyi ne şekilde kullanacakları, korunması gereken bir alanın nasıl korunacağı ve yerleşim düzenleriyle ilgili temel kuralları ihtiva etmesi gerekir (Kara, 2016: 47). İmar Kanunu'nda nazım imar planlarının süresine ilişkin herhangi bir sınırlama bulunmamaktadır. Uygulamada bu süre, başlarda 50 yıl olarak değerlendirilirken, önce 30 yıla sonra da 20 yıla düşürülmüş̧ür. Bu belirlemenin herhangi bir kanuni dayanağ bulunmadığı gibi, 20 yıllık gelişime göre yapılacak planlamanın, bölgesel ihtiyaçlar doğrultusunda öne çekilmesinin yahut uzatılmasının uygun olacağı şeklindeki doktrin görüşüne (Yıldız, 2012: 113) katılmaktayız.

Nazım imar planları, plan notlarıyla ve ayrıntılı raporla bir bütün olarak çizileceğinden, çizilerek açıklanamayan konuların, ek şeklinde plan notlarıyla paftalar üzerine yazılması gerekir. Nitekim, bu planlarda, farklı arazi kullanımları, genel kullanış şekilleriyle başlıca bölge tipleri ve yapılan nüfus tahminlerine göre belirlenecek nüfus dağılımlarına yer verilir. Ayrıca, plan dönemi sonunda varılması öngörülen kentsel gelişme hedefleri, üst plan ilke kararları ve hedeflere ulaşmada izlenecek kentsel gelişme stratejileri de hedef raporlarına 
yazılır (Kalabalık, 2014: 116). Plan notları, plan üzerinde ve plan lejantlarında ifade edilemeyen noktalarla plan kararlarını açık bir şekilde ifade etmek üzere plan paftaları üzerinde yer alan ve imar planı gibi kesin ve düzenleyici işlem olan notlardır (Çolak, 2010: 174). İmar planı ve ilgili plan notlarının, şehircilik esaslarıyla kamu yararına, planlama tekniklerine ve İmar Kanunu ve ilgili Yönetmeliklerine uygun bir biçimde hazırlanması gerekir. Mevzuata aykırı olan imar planı onaylanmışsa, tekrar değerlendirilerek mevzuata uygun hale getirilmelidir. Aksi durumun kabulü, hem planları onaylayan makamın sorumluluk altında kalması hem de olası olumsuzluklarda, çeşitli sorunların doğmasına sebebiyet verir.

Nazım imar planlarının hangi esaslar çerçevesinde hazırlanması/planlanması gerektiğine ilişkin hükümler, Mekansal Planlar Yapım Yönetmeliği'nin 23. maddesinde yer almaktadır. Buna göre; Uygulama imar planında yer alacak detaylar hakkında bir belirleme yapılmamalıdır. Çünkü, uygulamaya yönelik belirlemeler, nazım imar planında belirlenmez. İhtiyaç duyulursa, nazım imar planlarında da uygulama imar planına ilişkin yapım aşamaları gösterilebilir. Ulaşım sisteminin yolculukların mesafesini kısaltacak şekilde tasarlanması esastır. Parklar, çocuk bahçeleri ve oyun alanları, meydanlar, yeşil alanlar ile sosyal alanlar gibi kamuya açı yerlerin bir arada planlanmasına; ulaşım sistemlerinin de kısa mesafelere yayılmasının sağlanması esasına dikkat edilmelidir. Ancak, örneğin yeşil alanlar planlanırken, planlama tekniği ve şehircilik ilkelerinden bağımsız bir biçimde konut adaları içindeki bir taşınmazın büyük oranda yapılaşmamış kısmının yeşil alan olarak seçilmesinin, bu alanın bölgenin bütününe hitap eden ve yeşil alan sürekliliği oluşturacak özelliklere sahip olmadığı gerekçesiyle Danıştay tarafından iptal yaptırımına tabi tutulması da söz konusu olabilir (Danıştay 6. Daire, T. 7.5.2014, E. 2013/4085, K. 2014/3607). Nazım imar planları hazırlanırken, planlanacak bölgelerdeki yerleşim alanlarının karakteristiği, yenilenecek bölgelerin etütü, iklim özellikleri, hassas bölgeler, kültür ve turizm bölgeleri, sanayi merkezleri, demogrofik ve toplumsal yapı, ulaşıma ilişkin veriler, askeri bölgeler, doğal afet durumları ve mevcut arazi durumu gibi tüm verilere dikkat edilir. Doktrinde de ifade edildiği gibi, bu planlarda, nüfus yoğunlukları ve genel arazi kullanımı ile sosyal ve teknik donatı alanları da gösterilir. Bu yapılırken, parselleme işleminin alanına tecavüz edilmemesine dikkat edilmelidir (Bkz.: Kara, 2016: 48, dn. 82). Zaten, nazım imar planları uygulamaya yönelik kararları ihtiva etmez; yani uygulamalar uygulama imar planlarına göre gerçekleştirilir ve nazım imar planları, uygulama imar planlarına yön verecek temel verileri ihtiva eder (Çolak, 2010:175).

\subsubsection{Uygulama İmar Planlarının Yapılması}

İmar Kanunu'nun 5. maddesinde tanımlanmış olan uygulama imar planı; tasdik edilmiş halihazır haritalar üstüne çizilir ve mevcutsa kadastral durumu da ihtiva edecek şekilde nazım imar planlarına uygun bir biçimde yapı adalarını, bu adaların yoğunluğu ve düzenini, yolları ve diğer uygulama etaplarıyla ilgili bilgileri, ayrıntılı bir biçimde gösterir.

Mekansal Planlar Yapım Yön. 4. maddesinin (k) bendinde yapılmış olan tanıma göre ise, uygulama imar planı; ilgili bölgenin koşulları, planlanacak bölgenin özellikleri, yapıların kullanılış biçimi ve ihtiyaçlarla erişilebilirlik özellikleri ve çevresel etkileri dikkate alınarak çizilir. Yapı adaları, nizamı, yüksekliği, taban alan katsayıları, kat alanı kat sayıları yahut emsal yaklaşma mesafeleri; ön cephe, ifraz, kademe hatları ile tüm ulaşım vasıtalarının 
yolları, parklar, meydanlar, kentsel, sosyal ve teknik altyapı alanları bulunur. Gerekli görülürse, parsel büyüklüğü, parsel cepheleri ve derinlikleri, arka cephe hatları, bina kotu, bağımsız bölümler vb. yapılaşma ve uygulamaya yönelik kararlar ile diğer bilgilerin ayrıntılı olarak gösterildiği 1/1000 ölçeğe sahip halihazır haritalar üzerine işlenir. Aynı nazım imar planlarında olduğu gibi, plan notlarıyla ayrıntılı raporlar topyekün biçimde hazırlanır.

Uygulama imar planlarının hazırlanması sürecinde, kent imar planları için yapılan çalışmaların, toplanan verilerin ve yapılan değerlendirmelerin nazım imar planlarında da değerlendirilmesi mümkündür. Bu sebeple, onaylanmış halihazır haritalar üzerine çizilen uygulama imar planları, varsa kadastral durum da işlenerek paftalar belirlenir. Dolayısıyla uygulama imar planları yapılırken, kadastral durumun öğrenilmesi de önem arz eder (Kalabalık, 2014: 119). Uygulama imar planı, nazım planına uygun biçimde, lejant tekniği kullanılarak çizilir ve plan kararları, şekil, renk ve işaretlerle belirli edilir (Çolak, 2010: 175). $\mathrm{Bu}$ planlarda, yapı adaları içinde imar parselleri gösterilir ve çizim teknikleriyle sosyal ve teknik alt yapı standartlarına uygunluk aranır (Kalabalık, 2014: 119). Uygulama imar planlarına ait temel ilke ve esaslar Mekansal Planlama Yönetmeliği'nin 24. maddesinde gösterilmiştir. Buna göre;

- Uygulama imar planları, tek seferde yahut çeşitli unsurlar gözetilerek bölümler şeklinde de çizilebilir. -Nazım imar planlarında yer alan teknik ve sosyal altyapı bölgelerinin büyüklük ve konumlarının değiştirilebilmesi için, toplam standartların korunması, nazım imar planlarının süreklilik ve bütünlüğünün bozulmayacak şekilde hizmet alanına da riayet edilmesi gerekmektedir. -Nazım imar planlarında olmasa bile, uygulama imar planlarında, çocuk parkı, yeşil alan, araç parkları, bölgesel sağlık merkezleri, emniyet birimleri, mescit gibi küçük birimler, taşıt ve yaya yollarıyla bisiklet yollarına ilişkin ölçüler, bölgesel ihtiyaçlara paralel olarak eklenebilir/değiştirilebilir. -Bu planlarda, yapılara ilişkin, bitişik nizam, ayrık nizam, Taban Alanı Kat Sayısı (TAKS), Kat Alanları Kat Sayısı (KAKS), emsal oranlar, bina yüksekliği gibi hususlara yer verilir. -Yine, engelli, yaşlı ve çocukların ortak kullanım alanlarında kolaylaştırıcı tedbirler alınabilir, yeni tasarımlara yer verilebilir. -i̇lgili mevzuat hükümlerine göre korunan tescilli yahut tescilsiz tüm doğal ve kültürel varlıklarla bunların ayrılmaz parçaları, koruma alan sınırlarına ilişkin planlarda açıkça gösterilir. Nazım imar planında belirlenen karma kullanıma ilişkin fonksiyonların, bu plan türünde ayrılması gerekmektedir.

Uygulama imar planları hazırlanırken, planlanacak bölgelerde, belli başlı yerleşim bölgelerinde ilgili kurum ve kuruluşların verilerine ihtiyaç duyulmaktadır. Bunlara örnek olarak, alanların sınırı, yapı yoğunluğu ve doku, yapı adalarının özellikleri, yapı ve yaklaşma mesafesi, sosyal ve teknik altyapı olanakları, kamuya ait alanlar, tescilli anıtlareserler ve tarihi varlıklar ile göl, otopark, açık-kapalı alanlar, ulaşım hizmetleri tesisleri, toplanma alanlarıyla lojistik imkanların sağlandığı alanlar gösterilebilir (MPYY m. 24/10).

İmar planları yapılırken ve değiştirilirken, plan yapılan bölgenin imkanları ile ilerideki ihtiyaçları gözönünde tutularak, kentsel, teknik ve sosyal altyapı bölgelerinde Mekansal Planlar Yapım Yön. EK-2 başlıklı tablosunda belirtilmiş asgari şartlara uyulması gerekir (MPYY m. 11/I). Kentsel asgari standartların belirlenmesinde çevre düzeni planları kullanilabilir (MPYY m. 11/II). 


\subsection{3. İmar Planlarının Onaylanması}

\subsubsection{Planları Onaylayacak Makama Göre}

İmar planlarını ve bu planlar üzerinde değişiklik yapma yetkisi, esas olarak İmar Kanunu'nun 8. maddesi uyarınca mahalli idarelerdedir. Mahalli idareler içinde de, asıl yetki, belediyelerdedir (Kara, 2016: 67). Buna ek olarak, diğer mahalli idarelerle Çevre ve Şehircilik Bakanlığı'nın da imar planlarını onaylama yetkileri bulunmaktadır.

\subsection{Belediye ve Mücavir Alanlar İçinde Onaylanma}

Büyükşehir belediyesi sınırları içinde; büyükşehir belediyesi ve mücavir alan sınırları içinde kalan yerler için yapılacak olan planlar önce imar komisyonunda daha sonra büyükşehir belediye meclisinde görüşülür. Meclis, planlar üzerinde incelemelerini yapar ve varsa önerilerini bildirir. Bu sırada, planlamanın temel ilkelerine ve ilgili planın esas unsurlarına ters düşmeyecek şekilde revizyonlar yapılabilir. Bu şekilde görüşülen imar planları, İmar Kanunu'nun 8. maddesi gereğince, büyükşehir belediye meclisince kabul edilir ve onaylanırsa, yürürlüğe girer. Planların belediye meclisinde görüşülmesi sırasında, yapılan değişiklik ve düzeltmeler, kayıt altına alınarak arşivlenmesi amacıyla Çevre ve Şehircilik Bakanlığı'nın sistemine yüklenir ve bu işlem için bir plan işlem numarası oluşturulur.

5216 sayılı Büyükşehir Belediyesi Kanunu'nda (RG.: 23.7.2004, Sa.: 25531) imar planlaması konusunda yerel yönetimleri ilgilendiren önemli hükümler mevcuttur. Anılan Kanun'un belediyelerin görev ve yetkilerinin sıralandığı 7. maddesinin birinci fıkrasının (a) bendinde, çevre düzeni plânlarına uygun bir biçimde, büyükşehir belediyesi sınırlarında 1/5000 1/25000 ölçeklerindeki nazım imar plânlarını yapma, yaptırma ve onaylayarak uygulama yetkisi, büyükşehir belediyelerinin görevi olarak gösterilmiştir. Yine, büyükşehir sınırlarındaki belediyelerce hazırlanan uygulama imar planlarının ve plan değişikliklerinin onaylanması ve uygulanmasını denetlemek de büyükşehir belediyelerinin görev alanına girmektedir. Nazım imar planlarının yürürlüğe girdiği ilk bir yıl içinde, uygulama imar planıyla parselasyon planlarını yapmayan ilçe belediyelerinin, bu planlarını yapma veya yaptırma yetkisi de büyükşehir belediyelerine verilmiştir. 5216 sayılı Kanun'un 7. maddesiyle İmar Kanunu'nda öngörülmeyen nazım imar planlarının ölçeğine de yer verilmiş olmaktadır (Çolak, 2010: 137).

Büyükşehir Belediyesi Kanunu'nun 15. maddesinin birinci fıkrasına göre; büyükşehir belediye meclisinde, meclis üyelerinden seçilen en az beş, en fazla dokuz kişilik ihtisas komisyonları kurulması mümkündür. Aynı maddenin ikinci fıkrasına göre kurulması zorunlu komisyonlar arasında, imar ve bayındırlık komisyonu da gösterilmiştir. Planlar, imar ve bayındırlık komisyonunda görüşüldükten sonra büyükşehir belediye meclisinde karara bağlanır. Meclis toplantısından sonra, imar komisyonunun, en çok 10 işgünü içerisinde toplanarak, komisyona gönderilen planlama işlerini sonuçlandırması gerekir. Komisyondan, bu süre sonunda bir rapor çıkmazsa, konunun meclis gündemine alınmasına, meclis başkanlığınca karar verilir.

5216 sayılı Kanun'un 14. maddesinin ilk fıkrasıyla büyükşehir belediye başkanına, 7 günlük süre içerisinde, hukuka aykırı olduğunu düşündüğü meclis kararlarını, gerekçesiyle birlikte yeniden görüşülmek üzere, meclise gönderme yetkisi verilmiştir. Bu yolla yeniden görüşülmeyen yahut meclis tarafından direnilen kararlar kesinleşir. Belediye başkanının, 
ısrar edilen kararlar aleyhine idari yargıya başvurması mümkündür (BBK m.14/ III). Belediye meclisi kararları, kararın kesinleşmesinden sonraki yedi gün içerisinde mahallin en büyük mülki idare amirine gönderilmezse, yürürlüğe girmez (BBK m.14, IV, V) (Çolak, 2010: 140).

İlçe belediyelerinde; uygulama imar planlarını yapmakla yetkili ve görevli organ ilçe belediye meclisleridir (BBK m.7, I-b). İlçe belediyelerinin görev ve yetkilerinin sayıldığ 5216 sayılı Kanun'un 7. maddesinin ikinci fikrasının (a) bendine göre, mevzuat hükümleriyle büyükşehir belediyesinin yapmakla yükümlü kılındığı görevler ve aynı maddenin ilk fıkrasında sayılanlar dışındaki diğer işleri yapmak, ilçe belediyelerinin görevlerindendir. Bu nedenle, büyükşehir belediye meclislerinde, uygulama imar planlarının, onaylanması, ilçe belediye meclisleri tarafından yapılması gereken bir işlem olduğu için, o işlemin yetki yönünden hukuka aykırı olmasına sebebiyet verir. Büyükşehir Belediyesi Kanunu ile nazım imar planlarını yapma yetkisi büyükşehir belediyelerine, uygulama imar planı yapma yetkisi ise, ilçe belediyelerine vermiştir (BBK m. 14/ VIII; Ayrıca bkz.: BBK geçici m. 1). Ancak nazım imar planlarının yürürlüğe girdiği ilk bir yıl içinde, uygulama imar planıyla parselasyon planlarını yapmayan ilçe belediyelerinin bu planlarını yapma veya yaptırma yetkisi de büyükşehir belediyelerine verilmiştir (BBK m.7/ I-b) (Çolak, 2010: 138). 5393 sayılı Belediyeler Kanunu'nun (RG., 13.7.2005, Sa., 25874) 14/a maddesine göre belediyeler, bölgesel olan imar, trafik, çevre, kültür ve sanat, sosyal imkanlar, su ve kanalizasyon, ulaşım gibi kentsel hizmetleri yapmak/yaptırmakla ödevlidirler. Belediyenin belde ile ilgili imar planlarını görüşüp onaylamak, büyükşehir ve il belediyeleri sınırlarındaki il çevre düzeni planlarını kabul yetkisi, aynı Kanun'un 18/c maddesi ile belediye meclislerine verilmiştir (Çolak, 2010: 146). Belediye sınırları içinde kalan yerler için yapılan planlar önce imar komisyonunda daha sonra belediye meclisinde görüşülür.

Belediye Kanunu'nun 23. maddesinin ilk fikrasıyla belediye başkanına, 5 günlük süre içerisinde, hukuka aykırı olduğunu düşündüğü meclis kararlarını, gerekçesiyle birlikte yeniden görüşülmek üzere, meclise gönderme yetkisi verilmiştir. Bu yolla yeniden görüşülmeyen yahut meclis tarafından direnilen kararlar kesinleşir. Belediye başkanı, meclisin israrıyla kesinleşen planlar ve programlar aleyhine 10 gün içerisinde idari yargıya başvurabilir. Kesinleşen kararlar, en geç 7 günlük sürede, mahallin en büyük mülki idare amirine gönderilir. Mülki idare amirine gönderilmeyen plan ve programlar yürürlüğe giremez (Belediye K. m.23/ III, IV).

\subsection{Belediye ve Mücavir Alanlar Dışında Onaylanma}

Belediye ve mücavir alanlar dışında kalan yerlerde yapılacak olan imar planları, il özel idarelerince yapılır veya yaptırılır. İl Özel İdaresi Kanunu'nun (RG., 4.3.2005, Sa., 25745) 16. maddesine göre; il genel meclisi üyeleri arasından, meclis bünyesinde bir yıllığına görev yapacak bir imar ve bayındırlık komisyonu kurulur. Burada yapılan çalışmalar, il genel meclisine gönderilir. Aynı Kanun'un 10. maddesinin 1-c bendine göre, belediye sinırı il sınırlarıyla aynı olan büyükşehir belediyeleri hariç olmak üzere, il çevre düzeni planları ve belediye dışında bulunan alanlara ait imar planları il genel meclisinde görüşülür ve karara bağlanır. İl genel meclisince onaylanan planlar, 5 günlük süre içerisinde valiye gönderilir (İl Özel İdaresi K. m.15).

Belediye ve mücavir alanlar dışındaki yerler için valilik tarafından yahut ilgililerince hazırlanan/hazırlattırılan planların, yürürlüğe girmesi için valilik tarafından onaylanması 
gerekir. Onaylanan planlar, onaydan itibaren bir ay süreyle ilan edilir. Bu süre içerisinde valiliğe itirazda bulunulabilir ve bu itirazlar 15 gün içerisinde karara bağlanır (İmar Kanunu m. 8/II) (Çolak, 2010: 195). Vali, hukuka uygun planları onaylar; aykırı gördüklerini, gerekçeleriyle birlikte 7 gün içerisinde il genel meclisine iade edebilir. Bu kararlara il genel meclisince itiraz edilemez. (Çolak, 2010: 195).

\subsubsection{Planların İlanı ve Kesinleşmesi}

Mekansal Planlar Yapım Yönetmeliği'nin 32. maddesine göre, çevre düzeni planları, nazım imar planları ve uygulama imar planlarıyla bunlar üzerinde yapılacak değişiklik ve ilaveler, ilgili idarelerin karar mercileri tarafından onaylandığında yürürlüğe girerler. Burada istisnai bir durum vardır. $\mathrm{O}$ da, uygulama imar planlarının kesinleşmesi beklenmeden, imar uygulamasının yapılamamasıdır. İmar Kanunu'nun 8. maddesinin ilk fikrasının (b) bendine göre, belediye meclisince/il genel meclisince onaylanarak yürürlüğe giren imar planlarının hukuki anlamda geçerlilik kazanabilmesi ve hüküm ve sonuçlar doğurabilmesi için 1 ay boyunca ilana/askıya çıkarılması, gerekmektedir.

Doktrinde, buradaki kesinleşmenin yargısal anlamda bir kesinleşme olmayıp; kabul edilmiş olan imar planına göre işlem yapılabilmesi, planın uygulamaya konulabilmesi ve herkes için bağlayıcı hale gelmesi, yani idari anlamda kesinleşmesi anlamına geldiği ifade edilmiştir (Ergen, 2006: 672). Zira, imar planları, belediye meclisince onaylandığı andan itibaren, uygulanması mümkün bir idari işlem vasfı kazanır. İdari anlamda kesinleşip yürürlüğe girmiş bulunan imar planlarının ilana/askıya çıkarılması, aleniyeti ve planlara itiraz imkanı sağlamaktadır. Yapılan itirazın niteliğine ve önemine göre, planın kısmen yahut tamamen revizyon edilmesine karar verilebilir. Bu görev, belediye meclisine aittir.

\section{3. İmar Planlarının Hukuki Sonuçları}

\subsection{1. İdare Açısından}

İmar planlarının, mahalli idare sınıfında olan belediyeler ve merkezi idare kapsamında bulunan valilikler tarafından onaylanmasının en önemli sonucu, bu idarelerin organlarının, bu planları dayanak almak zorunda olmaları ve günlük iş ve işlemlerinde, daha dikkatli davranarak, planlara aykırı işlem yapmaktan kaçınmaları gerektiğidir. İdarenin bu bağlamdaki bir diğer yükümlülüğü de, imar planlarının uygulanması için gerekli tüm hazırlıkları ve düzenlemeleri yapmaktır (Kalabalık, 2014: 222-223).

İmar Kanunu'nun 10. maddesinin ilk fikrasıyla belediyelere, imar planlarının yürürlüğe girmesinden itibaren 3 ay içerisinde, ilgili planın uygulanabilmesi için 5 yıllık imar programı hazırlama ödevi getirilmiştir. Diğer bir yükümlülük de, imar ve yapı faaliyetlerini imar planındaki ilke ve kurallara göre gerçekleştirilmesini sağlama ve uygulamaları denetleme yükümlülügüüür. Yine planların aleniyetini ve dağıtımını sağlama ile ilgili birimlere gönderme yükümlülüğü hem İmar Kanunu hem de Mekansal Planlar Yapım Yönetmeliği kapsamında düzenlenmiştir (Kalabalık, 2014: 224-225).

\subsection{2. Özel Hukuk Gerçek ve Tüzel Kişileri Açısından}

İmar planlarının hukuki sonuçları, sadece idareler açısından değil, insanlar üzerinde de irdelenmelidir. Bu itibarla, plan yapılan bölgede yaşayan veya planlar sonucunda bunlardan etkilenecek olan kişilerin mülkiyet haklarına saygılı bir biçimde ve toplum yararı gözetilerek 
imar planı yapılmalıdır. Zira, imar planlarının, bir kent veya bölgedeki refah seviyesinin artırılmasına yardımcı olmak, gelişmeyi ve ilerlemeyi sağlamak gibi işlevleri de vardır. İmar planları, geleceğe dönük olarak uzun veya kısa vadeli kalkınmanın, yaşanabilir bir çevrenin anahtarı konumundadır. İmar planlarının, insanları, önceden belirlenmiş hedeflere yönlendiren, planlar doğrultusunda hareket etmeye yönlendiren olumlu bir boyutu olduğu gibi, planlara aykırı hareket edilmesini de önleyici bir işlevi yerine getirdiği için olumsuz bir niteliği bünyesinde barındırdığını ifade etmek gerekir (Kalabalık, 2014: 226).

Bu bağlamda özel hukuk gerçek ve tüzel kişilerine tanınan haklar şunlardır; imar çapını (durumunu) isteme hakkı, itiraz etme hakkı ve imar planlarına karşı dava açma hakkı.

İmar çapından maksat, ilgili parselin, imar mevzuatına uygun bir biçimde nasıl yapılaşacağına ilişkin durumunu, yapılaşmanın ana unsurlarını gösterir resmi bir belgedir. İmar planlama faaliyeti, bir kamu hizmeti olduğu için, bu belge, idari yargıya taşınabilecek, bireysel bir idari işlem kategorisindedir (Canbazoğlu ve Ayaydın, 2011: 278). Bir bölgede ilan edilen imar planlarının kesinleşmesiyle imar çapı, belediyeden istenebilir hale gelmektedir. Bununla o parselin imar planı kapsamında olup olmadığı, mevcutsa mevzuata göre belirlenmiş kat sayısı, yükseklik, derinlik, bahçe genişlikleri gibi mesafelere ilişkin hususlar krokide rakamla gösterilir (Kalabalık, 2014: 226-227).

İmar Kanunu'nun 8. maddesinin ikinci fıkrası ve Mekansal Planlar Yapım Yönetmeliği'nin 33. maddesine göre, çevre düzeni planı ve imar planlarının onaylanmasından itibaren 15 gün içerisinde, 30 günlük ilan süreci öngörülmüştür (Kalabalık, 2014: 228). Gerçek ve tüzel kişiler, imar planına veya yapılan değişikliklerine, ilgili idare nezdinde itiraz edebilir ve idare de 60 gün içerisinde açıkça kabul etmez veya cevapsız bırakırsa, itirazı kabul etmemiş sayılır. Bu sürede, idari işlem uygulanmaya devam edeceğinden, menfaatinin ihlal edildiğini düşünen kişilerin (örneğin, belde sakinleri, taşınmaz sahipleri vb.) ilgili idare aleyhine dava açması mümkündür (Kalabalık, 2014: 227). Zira, imar planları, doktrin ve yargı görüşlerine göre, düzenleyici idari işlemler arasında kabul edilmektedir (Kalabalık, 2014: 231; Canbazoğlu ve Ayaydın, 2011: 248-251. Aksi yöndeki görüş için bkz.: Tekinsoy, 2008: 48). İmar planı sonucunda, menfaatinin ihlal edildiğini düşünenler, imar planını, İdari Yargılama Usulü Kanunu'nun 2. maddesinde gösterilen iptal davası vasıtasıyla idari yargıya taşıyabilir. Davanın, planı onaylayan idareye karşı açılması gerekmektedir. Örneğin, Çevre ve Şehircilik Bakanlığı tarafından yapılan imar planlarının iptali, Danıştay'dan istenir (Canbazoğlu ve Ayaydın, 2011: 255-256). Ayrıca ilgililer planın uygulanması halinde, plana ve uygulama işlemine ayrı ayrı dava açabileceği gibi, birlikte de dava açabilir. Dava açma süresi imar planının ilanını izleyen günden itibaren 60 gündür (Kalabalık, 2014: 229).

\section{3. İMAR PLANLARINDA DEĞİŞIKLLIK YAPILMASI}

\section{1. İmar Planlarının Değişiklik Sebepleri}

İmar planları, estetik, düzenli, ileriye dönük ve sağl1klı bir şehirleşmede önemli bir rol oynamaktadır (Çolak, 2010: 198). Ancak, hem zamanın etkisi hem de diğer dış faktörler sebebiyle güncelliğini yitiren imar planlarının istenmese de planla varılmak istenen hedeflere ulaşılabilmesi için, nazım ve uygulama imar planında değişiklik yapılmaktadır. Buna mahal vermemek adına, ön çalışmalar yapılırken, toplanan veriler titizlikle incelenmeli ve fiziki ve sosyal yapıya uygun imar planları yapılmalıdır (Sancakdar, 1996: 143). Zaten, 
planlama hiçbir zaman matematiksel kesinlikte olamaz (Yıldız; 2012: 160). Dolayısıyla adeta yaşayan bir organizma gibi, devamlı değişen ve gelişen alanlara ilişkin uzun vadeli planların dönemin ihtiyaçlarına göre değiştirilmesi/revize edilmesi kimi zaman zaruret teşkil eder (Yayla; 2010: 199). Bu değişikliğin sebepleri, plan ömrünü uzatabilmek, değişen kamusal gereksinimler ve mülkiyet hakkı temelinde hak ve özgürlüklerin korunması şeklinde sayılabilir (Çolak, 2010: 199-203). Doktrinde, örnek olarak Trabzon Belediye Meclisine, Haziran 1989'dan Ekim 1993'e kadar 2722 adet değişiklik başvurusu yapıldığ1 ve bunların 780 tanesinin kabul edildiği aktarılmıştır (Ersoy, 2000: 3). Bu denli yüksek oranların, imar hukukunun temel ilkeleriyle bağdaştı̆̆ını söylemek oldukça zordur.

İmar planlarının değiştirilmesi, o planın çok kötü yahut eksik olduğu anlamına da gelmeyebilir. Çünkü, bir takım ekonomik, bilimsel ve fiziki zorluklar sonradan ortaya çıkabilir (Yayla; 2010: 199). Burada önemle ifade edilmelidir ki, imar planlarının değiştirilmesi, bir kural haline getirilmemeli, zorunlu ihtiyaçlar doğrultusunda, istisnai olarak başvurulması gerekli bir yol olarak görülmelidir. İmar planının değiştirilmesi son çare olarak görülmeli, mümkünse mevzuatta yer alan tüm imkanlar değerlendirildikten sonra değişiklik yoluna gidilebilmelidir.

Diğer idari işlemlerden farklı olarak, imar planları, her zaman değiştirilebilen, yerine yenisi getirilebilen idari işlemlerden değildir (Sancakdar, 1996: 144). Nitekim, diğer idari işlemlerde olduğu gibi, belirli şartların değişmesi halinde bu planlarda da değişiklik yapılabilse de, bu yola başvurulması, idari devamlılık ve kamu yararı ilkeleriyle desteklenmelidir. Mekansal Planlar Yapım Yönetmeliği'nin 26. maddesinin ilk fıkrasına göre, imar planı değişikliklerinde, plan ana kararının devamlılık ve bütünlüğüyle teknik ve sosyal altyapı dengesini bozmadan, kamu yararı gözetilerek, teknik gerekçelere dayanılmalıdır. Değişiklikler, planların yapılması usulüyle paralel bir biçimde gerçekleştirilir. Yani, imar planlarının değiştirilmesi, yetki ve usulde paralellik ilkesi gereğince ilgili belediye meclisi yahut il genel meclisi tarafından, etkileniyorsa ilgili Bakanlık veya kuruluşun görüşü alınarak gerçekleştirilir (Bilgin ve Sezer, 2014: 103).

İmar planı değişikliklerinde, aynı planların yapılmasında olduğu gibi kamu yararı ilkesi de gözetilir. Buna ek olarak, Danıştay tarafından geliştirilmiş bir kavram olarak imar planı değişikliklerinde dikkate alınan "üstün kamu yararı" kavramı vardır. Buna göre, örneğin sağlık hizmetlerinin etkin ve yaygın biçimde sunumu amacıyla bu hizmetin yürütülmesine yönelik tasarrufların da üstün kamu yararı başlığı altında değerlendirilmesi söz konusudur. Bu bağlamda, hastane binalarında yürütülecek hizmetin niteliği gereği ve hizmete uygun yapılaşma koşulları belirlenirken üstün kamu yararı ilkesinden hareketle şehircilik ilkeleri ile planlama esasları, somut duruma göre tekrar değerlendirilebilmektedir (Danıştay 6. Daire, T. 28.3.2014, E. 2013/1015, K. 2014/2428).

\section{2. İmar Planlarının Değişmezliği İlkesi}

Yürürlüğe girmiş ve kesinleşmiş olan imar planları, bir bölgenin tüm fiziki, sosyal ve teknik şartlarına yön vermektedir ve bu yüzden o bölgeye ait en önemli yol haritası konumundadır.

İmar planlarının hazırlanması aşamasında, hedefler düzgün belirlenir, toplanan veriler doğru değerlendirilir ve geniş kapsamlı ve çoğulcu düşünce benimsenirse, detaylı ve titiz bir süreç yürütülmüş olur ve bu da imar planının uzun vadeli, sağlam bir plan olması anlamına 
gelir. Mevcut bir imar planında ne kadar çok değişiklik ve revizyon yapılırsa, o planın inandırıcılığı ve verdiği güven azalmaktadır. Bunun olmaması için, daha hazırlık aşamasından itibaren titiz davranılmalı, bilimin verileri ışığında mümkün olan en uzun vadeli plan yapılmalıdır. Bu davranış biçimi, her zaman olumlu sonuç vermeyebilir. Nitekim, gerçekten devamlı hareket ve değişim içerisinde olan dünyamız, kentsel bazda da yerinde saymamakta, içinde bulunulan şartlar değişebilmekte ve bu da imar planlarının değiştirilmesi ihtiyacını doğurmaktadır (Demir, 2009: 48). Zaten, ihtiyaçları karşılamaktan uzak ve güncel olmayan bir imar planı üzerinde ssrar etmenin faydasız olduğunun anlaşılması üzerine, varsa düzeltilebilir hataların ele alınması daha doğru bir yaklaşım olacaktır.

Mekânsal Planlar Yapım Yönetmeliği 24. maddesinin ikinci fıkrasında nazım imar planlarının uygulama imar planı vasıtasıyla değiştirilebileceğine işaret edilmiştir. Bunun için gerekli olan şartlar, alan büyüklüklerinin belirli sınırların altına düşülmeden, ana kararların süreklilik, bütünlük ve işleyişini bozmadan, ilgili kurum ya da kuruluşların da görüşlerinin alınarak yapılmasıdır. Burada getirilen şartlar, plan değişikliğinin sınırlarını belli etmek ve imar planlarının devamlı değiştirilememesini sağlamaktır (Kalabalık, 2014: 183).

Daha önce de ifade edildiği gibi, planların değiştirilemezliği kural olmakla birlikte belirli şartların gerçekleşmesi halinde imar planları da değiştirilebilir". Her kuralda olduğu gibi burada da belli başlı istisnalar öngörülmüştür. Önemli olan, bu istisnaların genişletilmemesi, bazı zorunluluklar ve kamu yararı haricinde her durumda devreye sokulmamasıdır. İmar planları değiştirilirken, göz önünde bulundurulması gereken bu esaslara uyuşmazsa, yargıya başvuru ve iptal davaları söz konusu olabilir. Plan değişikliğinde dikkate alınması gereken esaslar, şehircilik ve planlama ilkelerine uygunluk, plan bütünlüğüne ve plan ana kararlarına uygunluk, kamu yararına uygunluk olarak sıralanabilir (Demir, 2009: 49).

\section{3. İmar Planlarında Değişiklik Usulleri}

\subsubsection{Mekansal Planlar Yapım Yönetmeliği Hükümlerine Göre Plan Değişikliği}

İmar Kanunu'nun 8. maddesinde tanımlanan nazım ve uygulama imar planları, ilgili belediyelerce yapılır/yaptırılır ve belediye meclisince onaylanarak yürürlüğe giren, düzenleyici idari işlemlerdendir (Kalabalık, 2014: 231). İmar planı değişikliğii, Mekânsal Planlar Yapım Yönetmeliği'nin 26. maddesinde düzenlenmiştir. Buna göre, İmar planı değişikliklerinin, plan ana kararlarının süreklilik, bütünlük ve dengesini bozmayacak şekilde kamu faydası güdülerek, nesnel ve teknik gerekçelere dayanılarak yapılacağına işaret edilmiştir. Mekânsal Planlar Yapım Yönetmeliği'nde çevre düzeni planı üzerindeki revizyona ve değişikliklere ilişkin şartlar belirlenmiştir. Anılan Yönetmeliğin 20. maddesinin ilk fıkrasına göre, bölgede yaşayanların ihtiyaçlarının karşılanamaması, önemli ve büyük ölçekte planı etkileyebilecek yeni yatırımların varlığı, güncel verilere göre farklı arazi şartlarının ortaya çıkması, yeni ve bölgesel gelişmelerin varlığı hallerinde plan revizyonu

\footnotetext{
${ }^{4}$ Alt kademedeki idarelerin yaptı̆ı̆ planların üst kademe idareler tarafından değiştirilebilmesinin, işlem güvenliğini tesis ve yetkide paralellik ilkeleri gereğince, sınırlı olması gerekmektedir. Örneğin, ilçe belediyesi tarafından yapılmış bir planın, büyükşehir belediyesi tarafından değiştirilmesi, kamu yararının gerektirdiği hallerde veya bölgenin koşullarına göre zorunluysa mümkün olmalıdır. Bu ilke kabul edilmezse, yetki alanına müdahale ve belki bölgeye tam uyacak bir planın işlevini yapamaması söz konusu olabilir.
} 
yapılabilir. Aynı maddenin ikinci fıkrasında çevre düzeni planı ana kararlarının, sürekliliğini ve bütünlüğü bozmayan plan değişikliklerine izin verileceğine işaret edilmiştir.

\subsubsection{Sosyal ve Teknik Altyapıya İlişkin Değişiklikler}

Mekansal Planlar Yapım Yönetmeliği'nin 26. maddesinin üçüncü fikrasına göre; imar planlarındaki teknik ve sosyal altyapı bölgelerinin iptali, boyutunun veya yerinin değiştirilmesine ilişkin değişiklikler, zorunlu haller haricinde yapılamaz. Bu planların değiştirilebilmesi için varlığı gerekli zorunlu hallere ilişkin şu şartlar aranır:

- Teknik ve sosyal altyapı alanında plan değişikliğini gerektiren yatırıma ilişkin ilgili Bakanlık ya da kurum ve kuruluşların görüşüne başvurulur (MPYY m. 26/III-a). - Ulaşım yolları hariç olmak kaydıyla teknik ve sosyal altyapı alanlarının ve kamunun sosyal tesislerinin kaldırılması ya da küçültülmesi, bunların alternatiflerinin planlanması halinde mümkündür. Alternatif-eşdeğer alanlar belirlenirken, önceki planla büyüklük ve yer bakımından benzerlik kriteri esas alınır. Yeni yapılacak alanın, eskisiyle aynı bölge içinde bulunmasına, gördüğü hizmetin benzer olmasına ve tesisleşmeye müsait olmasına dikkat edilir (MPYY m. 26/III-b). Yani teknik ve sosyal altyapı alanlarının değiştirilmesi için, yalnızca zorunluluk şartı değil, eşdeğer yeni bir alanın benzer şartlara uygun biçimde planlanmış olması gerekir.

Plan değişikliği sonucunda değiştirilen yol alanları, park ve çocuk bahçesi, meydan gibi açık, yeşil bölgelerde kullanılabilir. Burada, düzenlenen alanların yüzölçümlerinin eski alandan daha az olmamasına dikkat etmek gerekir. Yine, yol alanlarının dışındaki alanlarda, kamuya ait bir ortaklık payına tabi kullanıma dönüştürülmesi isteniyorsa, ortaklık payına tabi alanın etkileyeceği alana eş başka bir alan belirlenir (MPYY m. 26/III-c). Uygulama imar planları bağlamında, teknik ve sosyal altyapı alanlarında değişiklik yapılabilmesi için, toplam standartların altında olmamak kaydıyla nazım imar planlarında belirtilen ilkeler çerçevesinde, ilgili kurumlardan da görüş alınmak suretiyle ve konum ile büyüklük itibariyle azaltılmaması kaydıyla değiştirilebilir (MPYY m.24/II).

\subsubsection{Kat Sayısına ve Bina Yüksekliğine İlişkin Değişiklikler}

Mekansal Planlar Yapım Yönetmeliği'nin 26. maddesinin beşinci fıkrasına göre; imar planlarında yer alan inşaat emsallerinin, kat sayılarının ve ifraza ilişkin şartların revizyonu halinde, nüfus yoğunluğunun arttırılmasına dair plan değişikliğinde uyulacak esaslar şu şekildedir:

- Planı değiştirilecek bölgede yer alacak teknik ve sosyal altyapı alanları, artan nüfusa orantılı olarak belirlenir (MPYY m. 26/V-a). -Kat sayısı, nüfus yoğunluğundan bağımsız olarak arttırılmak isteniyorsa, belirlenecek kat sayılarının belirli uzaklık hesaplamalarına göre yapılması gerekmektedir. Bu formül sayesinde, karşılıklı duran binalar arasında asgari mesafe korunacaktır (MPYY m. 26/V-b). -Yönetmeliğin 26. maddesinin beşinci fıkrasının (b) bendinde gösterilen formül, yapı düzeni değişiklikleriyle parsel birleştirmede, kat sayısının artırılabilmesi için de kullanılır (MPYY m. 26/V-c). 


\subsubsection{Yolların Genişletilmesi, Daraltılması ya da Güzergahlarının Değiştirilmesiyle İlgili Değişiklikler}

Yolların, genişletilmesi ve daraltılmasıyla güzergahlarına ilişkin imar planları değiştirilirken uyulması gereken esaslar (Yıldız, 2012: 133-134) şunlardır;

- Devamlılığı bulunan yolların şerit sayılarının azaltılması ve daraltılması işlemi, belirli bir bölüme özgü olarak yapılamaz (MPYY m. 26/VI-a). -Yollar kaydırılırken, ilgili bölgedeki mülkiyet durumuna ve yapıların konumlarına göre hareket edilir (MPYY m. 26/VI-b). Gelişme alanı olarak planlara işlenen yerlerde, yaya yolları ve trafik yollarına ilişkin asgari standartlar, 3 ve 10 metre olarak belirlenmiştir. Yine, mülkiyet durumu ve yapıların konumları dikkate alınır. Parsellerin mahreç yeri olarak 7 metrenin altındaki parseller belirlenemez (MPYY m. 26/VI-c). -Plan değişikliğiyle, taşıtların geri dönenemeyecekleri şekilde çıkmaz sokaklar belirlenemez (MPYY m. 26/VI-ç). -Plan yapılacak yerde bulunan trafik yoğunluğuna göre, ileride doğabilecek taşıt yolu ve kaldırım ihtiyacı da hesaba katılmalıdır (MPYY m. 26/VI-e).

\subsubsection{Yoğunluk Artıran veya Kentsel Ulaşım Sistemini Etkileyen Değişiklikler}

Şehiriçi ulaşımı etkileyebilecek, yoğunluğu artıracak plan değişikliklerinde teknik ve sosyal altyapıya ilişkin verilerin toplanarak titizlikle irdelenmesi; varsa alınması gereken önlemlerin alınarak kentsel teknik altyapı etki değerlendirmesi raporu, hazırlatılır (MPYY m. 26/VII).

\subsubsection{Yerel Yönetimlerce Re'sen Değişiklik Yapılması}

Yetki ve şekilde paralellik ilkesinin doğal bir sonucu olarak, imar planlarında değişiklik yapma yetkisi esas olarak belediye meclisine aittir. Bu duruma, İmar Kanunu'nun 9. maddesinin üçüncü fıkrasıyla da işaret edilmiştir (Kalabalık, 2014: 185-186).

\subsection{3. Çevre ve Şehircilik Bakanlığı'nca Değişiklik İstenmesi}

Çevre ve Şehircilik Bakanlığı da, imar ve yerleşim planlarını değiştirmeye ve re'sen onaylama konusunda yetki sahibidir. Bu yetkinin kapsamina giren haller; kamu tesisleri ve enerji tesisleri ile ilgili alt/üst yapı ile enerji iletim hatlarıyla ilgili değişiklikler; doğal afet ya da toplu konut yapılması gibi plan değişiklikleri, birden fazla belediye alanını ilgilendiren planlar veya bulunduğu bölgeden (deniz, kara, hava vb.) taşıt yolu geçen yerlerde yapılacak değişikliklerdir. Bu değişikliklerin yapılmasında, ilgili belediye ve kamu kurumlarıyla bilgi paylaşımı yapılması ve işbirliği yapılması da şarttır (Kalabalık, 2014: 149, 185).

$\mathrm{Bu}$ yetkilerin yanında, Bakanlık, kamu hizmeti amacıyla resmî yapılarda değişiklik yapılması gerektiğinde, valilik kanalıyla ilgili belediyeye talimat verebilir. Gerekli görülürse, imar planı re'sen Bakanlık tarafından yapılıp onaylanabilir (Kalabalık, 2014: 185). Yine Bakanlığa, ilgili kamu kurumu ve kuruluşlarla işbirliği yaparak, mekânsal strateji planlarını hazırlama ve mahalli idarelerin plan kararlarının bu planlara uygun olup olmadığını denetleme yetkisi de verilmiştir (Kalabalık, 2014: 185, 191).

\subsection{4. Özel Hukuk Gerçek veya Tüzel Kişilerince Değişiklik İstenmesi}

3194 sayılı İmar Kanunu'nda belediye ve mücavir alan sınırları içinde, imar planlarının belediyelerce yapılacağı veya yaptırılacağı düzenlemesinde önemli olanın planların, 
belediyelerin hangi organları tarafından yapılacağının değil, planların onaylanması olduğu doktrinde ifade edilmiştir (Kalabalık, 2014: 186). Mekânsal Planlar Yapım Yönetmeliği'nin 31. maddesinin son fıkrasında, imar planı tekliflerinin planların kapsadığı bölgenin sahipleri ya da bunların vekilleri tarafından sunulabileceği hüküm altına alınmıştır. Burada, plan değişikliklerine özel hukuk gerçek ve tüzel kişilerinin bu aşamada dâhil olabilecekleri ifade edilmektedir (Kalabalık, 2014: 186-187). Zira Danıştay'ın özel hukuk gerçek veya tüzel kişilerince imar teklifinde bulunulmasına olanak tanıdığı kararlar bulunmaktadır (Kalabalık, 2014: 186, dn.10).

\section{IMAR PLANLARININ ORTADAN KALDIRILMASI}

\section{1. İmar Planlarının İptal Davası Açılarak Sona Erdirilmesi}

\subsubsection{Genel Olarak}

İmar planı hazırlanması ve değişiklikleri düzenleyici idari işlem kategorisindedir. Dolayısıyla idari yargıda iptal davası açılması suretiyle iptal edilebilmeleri de mümkündür. İdari yargı organının önüne götürülen idari tasarrufun, üst ölçekteki planlara uygunluğu gibi imar mevzuatına uygun olup olmadığı̆, incelenecektir. Ancak bu incelemenin yapılabilmesi için de, öncelikle şekil şartlarının sağlanmış olması aranmaktadır (Davut ve Coşkun, 2011: 1213). Bu nedenle yapılan imar planının, iptal davasına konu edilebilmesi ve esastan incelenebilmesi için yetki/görev, ehliyet, kesin ve yürütülmesi gerekli bir işlemin varlığı, süre ve husumet yönlerinden bir eksiklik bulunmaması gerekir (Canbazoğlu ve Ayaydın, 2011: 254-281; Davut ve Coşkun, 2011: 1213). Dava, bir aylık ask1 süresi içinde 2577 sayılı Kanun'un 11. maddesi kapsamında başvuruda bulunulması ve bu başvuruya idari dava açma süresinin başlangiç tarihi olan son ilan tarihini izleyen günden itibaren 60 gün içinde cevap verilmeyerek isteğin reddedilmiş sayılması halinde, bu tarihi takip eden 60 günlük dava açma süresi içinde veya son ilan tarihini izleyen günden itibaren 60 gün içinde cevap verilmek suretiyle isteğin reddedilmesi halinde bu cevap tarihini izleyen günden itibaren 60 günlük dava açma süresi içinde açllabilir (Danıştay 6. Daire, T. 15.10.1998, E.1997/5279, K. 1998/4592).

Örneğin, iptal davasının menfaati ihlal edilenler tarafından ve İmar Kanunu'nun 8. maddesinin (b) bendinde belirtilen bir aylık ilana itiraz süresinin dolmasından veya bu sürede itiraz edilmiş ve reddedilmişse ya da zımni ret edilmiş sayılmışsa bundan itibaren genel dava açma süresi olan 60 gün içerisinde (İdari Yargılama Usulü Kanunu m.7/I) açılması gerekmektedir. Aksi halde dava, dava süre aşımı nedeniyle reddedilecektir (Davut ve Coşkun, 2011: 1210; Danıştay 6. Daire, T. 28.3.2014, E. 2013/1015, K. 2014/2428; Danıştay 14. Daire, E.2011/13742, K. 2011/796).

\subsubsection{Davada Menfaat ve Görevli Yarg1 Yeri}

Bir imar planının iptali için dava açılması halinde, yukarıda işaret ettiğimiz unsurlar yanında, daha önce de belirtmiş olduğumuz süre ve menfaate ilişkin hususlar da dikkate alınarak kapsamlı bir denetim yapılır. Hukuka aykırı bir biçimde yapılmış veya değiştirilmiş imar planlarının menfaat sahibi kişi veya kurumlar tarafından itiraz edilmesi mümkündür. İlgili idarenin itirazı reddetmesi ya da reddetmiş sayılması halinde, idari yargıda, menfaati ihlal edilen her gerçek ve tüzel kişi tarafından, iptal sebebiyle yasal (60 gün) sürede dava açılabilir (Öz, 2011: 83-84). İptal davalarında görevli yarg1 yeri, planın onaylandığ1 yerdeki 
bölge idare mahkemesi ya da ilk derece mahkemesi sıfatıyla Danıştay'dır (Danıştay Kanunu m.24/I-c). Yine bölge idare mahkemelerince veya Danıştay dairelerince verilen imar planı ve parselasyonuna ilişkin işlemlerden kaynaklı davaların temyiz mercii Danıştay'dır (IYYUK m.46/I-f).

İptal davası açılabilmesi için davacı ile dava konusu işlem arasında kişisel, meşru ve güncel bir hukuki yararın bulunması gerekmektedir. Bu hem özel hukuk yargılamasında hem de idari yargıda kabul edilmiş genel bir ilkedir (Ayrıca bkz. Hanağası, 2009: 3 vd.). Bu ilkenin esası, dava açılabilmesi için, ilgilinin güncel ve korunmaya değer bir menfaatinin bulunması olup, ilgisiz kişilerin dava açması, yargılama makamlarının gereksiz iş yüküyle karşılaşmasına sebep olabilecektir. İmar hukukunda, dava açmakta menfaati bulunan kişiler, genel itibariyle imar planı veya değişikliği yapılan il veya ilçede ikamet eden veya o il ve ilçede taşınmazı bulunan gerçek ve tüzel kişiler olarak kabul edilmektedir (Çiçek, 2016: 104). İlgili il veya ilçede ikamet etmeyenlerin ya da taşınmazı bulunmayanların, dava açmakta menfaatlerinin bulunduğunu ayrıca ispatlamaları gerekmektedir. Kimi durumlarda mülkiyet hakkı sahipleri, kimi durumlarda da plandan doğrudan etkilenen kişiler davacı olabilir (Çolak ve Öngören, 2014: 146-147). Bu konuda, mevzuatta bir açıklık bulunmadığından, çoğunlukla Danıştay içtihatları yol gösterici olmaktadır. Örneğin, belediye meclis üyesi tarafından, kamu yararını yakından ilgilendiren uyuşmazlık konusu plan değişikliklerine karşı mevzuata uygun şekilde itirazda bulunmasından sonra, itirazın reddine dair işlem üzerine dava açması mümkündür. Bununla birlikte, bu meclis üyesinin, hak ve menfaatlerini korumakla görevli olduğu ve belediye seçimleri esaslarına göre temsil ettiği belde halkının da itirazın reddi halinde dava açabileceği kabul edilmektedir (Danıştay 6. Daire, T. 29.4.2014, E. 2013/1569, K. 2014/3436).

Danıştay, 8.6.2011 tarihli başka bir kararında ise, temel işlevleri örneğin avukatlık mesleğini geliştirmek, hukukun üstünlüğünü, insan haklarını savunmak ve korumak olan baroların, görevleri göz önüne alındığında, bir yapı emsalinin yükseltilmesi ve yapılanma şartlarının belirlenmesine ilişkin plan değişikliğinin davacı Baronun doğrudan tüzel kişiliğini, hak ve menfaatlerini etkilemediğinden bahisle, sübjektif ehliyet koşulu olan menfaatinin ihlal edilmediğine karar vermiş ve somut olayda baroların davacı olamayacağını belirtmiştir (Danıştay 6. Daire, E.2010/12920, K.20211/2120). Yine başka bir kararda, imar planı iptali talep eden bir siyasi parti il başkanının başvurusunu kabul etmemiştir (Danıştay 6. Daire, T.4.10.2001, E.2000/3480, K.2001/4259: Canbazoğlu ve Ayaydın, 2011: 265-266). Çoğunlukla tartışma konusu olan çevre davalarında, menfaat ihlali için vatandaş olmak da yeterli sayılabilmektedir. İmar planlarına yapılan itirazlardan farklı olarak, imar planının doğurduğu sonuçlardan etkilenmek şartı, çevre davalarında aranmamaktadır (Çiçek, 2016: 104-105). Danıştay, bir kararında imar planına bahse konu taşınmaza komşu taşınmaz sahibinin de menfaatini kabul etmiştir. (Danıştay 6. Daire, T.9.7.2003, E.2003/1712, K.2003/4221: Canbazoğlu ve Ayaydın, 2011: 265-266).

Sonuç olarak, kural, planların yapılması veya değiştirilmesi nedeniyle menfaati ihlal edilen her gerçek ve tüzel kişinin dava açma ehliyetine sahip bulundukları, bu konuda menfaat şartının gerçekleşmiş olduğudur. Ancak, menfaat, her somut olay bağlamında ayrı ayrı denetlenmeli, dava konusu işlem ile o davacı arasındaki güncel, meşru ilişki değerlendirilmelidir. Zira, bu konuda net bir belirleme doktrinde ve içtihatlarda 
yapılmamakta, bazı durumlarda hak ihlali boyutuna varan ihlallerin varlığı aranmaktadır (Canbazoğlu ve Ayaydın, 2011: 265-266).

\subsection{3. İptal Davasının Konusu ve İncelenecek Hususlar}

İmar planlarının iptali davasında şekil yönünden bütün şartların sağlanarak açıldığı anlaşıldığında, esastan incelemeye geçilir ve burada da idare hukukunun temel ilkelerinden olan yetki, şekil, sebep, konu ve maksat unsurları açısından bir inceleme yapılır. Zira işlemi tesis eden idarenin, kanun ve diğer mevzuata uygunluğu sağlaması gerekir; aksi halde iptal yaptırımıyla karşı karşıya kalınacaktır (Öz, 2011: 82).

İmar Kanunu'nda kendisine yer verilen imar planları; nazım imar planı, uygulama imar planı, çevre düzeni planı ve metropoliten imar planlarıdır. İmar planlarının yapımıyla ilgili temel kurala daha önce de değinmiştik. Buna göre, belediye sınırları içerisinde, nazım imar ve uygulama imar planları, varsa bölge ve çevre düzeni planlarına uyumlu bir biçimde yapılırken, belediye meclisi tarafından onaylanır. Bu plânlar onaydan itibaren bir aylık ilan süresinde ilan edilir ve itiraz gelmezse kesinleşir, itiraz yapılırsa 15 gün içerisinde belediye meclisince incelenir ve kesin olarak karara bağlanır. Belediye sınırları dışında kalan yerlerde ise valilik ya da ilgililerince yapılan planlar, valilik tarafından onaylandığında yürürlüğe girer. Yine belirlenen yerlerde ve internet ortamında bir aylık ilan süresi vardır ve yapılan itirazlar, valilikçe incelenir ve 15 gün içerisinde kesinleştirilir. Planların değiştirilmesi halinde ise, değişikliklerin de ilan edilmesi gerekir ve bu ilanın nerede yapılacağı hakkında ilgili muhtarlıklarda bir duyuru yayınlanır ve aynı zamanda, 30 gün boyunca ilanda olacak şekilde plan değişikliği hakkında, planın yapıldığı yerde bilgilendirme panoları asılır (İmar K. m. 8/III). Danıştay 6. Daire'nin 2013/6634 E., 2014/3737 K. sayılı ve 14.5.2014 tarihli kararında, planların usulüne uygun bir biçimde sürelere uyularak ilan edilmesinin yeterli olmadığı, planın nerede nasıl görülebileceğinin mahalli haberleşme araçları ile de duyurulmasının gerektiği, dava açma süresinin bu ilanın öğrenildiği beyan edildiği tarihte başladığ 1 ifade edilmiştir.

İmar planlarının idari yargıda iptal davasına konu edilmesi halinde, idare hukukunun ilkeleri açısından bir irdeleme ve değerlendirme yapılacaktır. Bunlardan ilki yetki unsurudur. Buna göre, belediye ve mücavir alanlarda yapılacak imar planlarında karar organı, belediye meclisidir. Dolayısıyla, belediye meclisi haricinde, örneğin belediye başkanı tarafından imar planı yapım kararı alınması halinde, hukuka aykırılık meydana gelmiş olacaktır. Yine, belediye ve mücavir alanları dışındaki yerlerde planların valilikler ya da ilgililerince yapılması/yaptırılması gerekirken, yetkisiz bir kurum tarafından yapılırsa, yetki tecavüzünden bahsedilebilir (Öz, 2011: 83).

İdari işlem ve kararlar, belirli şekil kurallarına uyularak yapılmalı ve alınmalıdır. Bu sebeple, şekil, idari işlem ya da kararların temel unsurlarından birisidir (Günday, 2003: 132). İmar planları bağlamında da çeşitli şekil şartları varsa, bunların tam ve eksiksiz bir şekilde yapılmış olması aranmaktadır. Buna örnek olarak, planların yazılı olması, imza ve ilan gibi asli unsurları bünyesinde barındırması gösterilebilir. Nitekim, yukarıda belirttiğimiz gibi imar planlarının yapılmasından ve onaylanmasından sonra belirli süreyle ilan edilmesi ve duyurulması gerekmektedir. Bu askı ve ilan süresi tamamlanmadan dava açılırsa, şekil eksikliği sebebiyle planların iptali söz konusu olabilir. 
İdari işlemler, yapılmalarından önce var olan ve pozitif hukuk kurallarıyla hüküm altına alınmış bir sebebe dayanmalıdır. Bu itibarla sebep unsuru, o idari işlemden önce gelen ve idareyi bu işlemi yapmaya sevk eden fiil veya nesnel bir hukuki durumdur. İdari işlemin sebebi, idareyi o işlemi yapmaya iten etkenlerdir (Günday, 2003: 138; Öz, 2011: 83). İdari işlemlerin amacı genel olarak, idari görevlerin düzgün yürütümü ve toplumsal gereksinimlerin karşılanmasıdır. Yani, kamu yararı güdülerek yapılan işlemlerdir ve imar planlarının da sebebi, hukuka ve kamu yararına uygun olmalıdır. İdareyi bu planları yapmaya veya değiştirmeye iten sebepler, plan ekinde veya açılamalarında gösterilmelidir. Zaten, bir idari işlemin kendisinden beklenen faydayı göstermesi de buna bağlıdır (Günday, 2003: 139).

İdare hukukunda, irade özerkliği ve sözleşme serbestisi bulunmadığı için, işlemlerin konusunu belirleme yetkisi idarelerin iradesine bırakılmamıştır. Yine, bir idari işlemin konusu imkansız ya da hukuka aykırı olamaz. Bununla birlikte, idari işlemin konusu, o işlemin doğuracağı hukuki sonuçtur ve idari işlemin sebep unsuruyla sıkı ilişki içerisindedir (Günday, 2003: 145). İdari işlemin doğuracağı sonuç, yasal mevzuatla daha önceden belirlenmiş sonuca uygun olmalıdır. İmar planlarının da, yasal mevzuata ve sebep unsuruna bağlı bir şekilde konu yönünden hukuka uygun olması, imar mevzuatı çerçevesinde yapılmasına bağlıdır (Öz, 2011: 83).

Maksat unsuru, kanun koyucunun, o idari işlemle ulaşmak istediği ve beklediği nihai sonuç olarak tanımlanmaktadır (Günday, 2003: 146). İdari işlemler, toplumsal yararın gerçekleşmesini amaçladıklarından, maksat unsurundan da toplumsal ihtiyaçların gözetilerek kamu hizmetlerinin yerine getirilmesi anlaşılır. Kamu yararı, tüm idari işlem ve kararlar ilin değişmez, nihai bir hedef olduğundan, bireysel ve kişisel diğer çıkarların güdülmesi halinde, idari işlem veya kararlar hukuka aykırı hale gelir (Günday, 2003: 146). Bir hukuk devletinde, kişisel amaç güdülerek alınmış, siyasi amaç güdülerek alınmış ve maksadı aşan kararın alınmış olması, yargı denetimine tabi olup her zaman iptal edilmeleri mümkündür. İmar planları bağlamında da, belirli bir kesim ya da çıkar grubunun faydasına olacak şekilde imar düzenlemesi yapılması, idari yargıda iptal sebebi teşkil edecektir.

\section{2. İmar Planlarının İdare Tarafından Sona Erdirilmesi}

İmar planlarının son erdirilmelerinde, yine idare hukukunda geçerli olan yetkide ve şekilde paralellik ilkesi gereğince, planı yapan veya yaptıran idarenin yetkili olduğu söylenmelidir. $\mathrm{Bu}$ noktada, gerek yeni bir plan çıkartılarak eski planın ilga edilmesi, gerekse halihazırdaki plan üzerinde değişiklikler yapılarak eski planın güncellenmesi/geliştirilmesi söz konusu olabilmektedir. Yeni plan çıkartılmadan yapılan önemli değişikliklerin önemli bir boyutta olması durumunda, eski plan adeta ortadan kalkmakta ve yeni bir plan ortaya çıkabilmektedir. Dolayısıyla, bu değişikliklerin yapılmasında, daha önce de değindiğimiz idare ve imar hukukunun temel ilkeleri gözetilerek, kamu yararı ve toplumsal fayda çerçevesinde hareket edilmelidir. Yakın zamanda yaşanan İzmir depremiyle de tartışma konusu yapılan imar planlarının ve projelerinin yetersizliği ile idarelerin bu konudaki denetim eksikliği, kazanılmış hak ilkesi çerçevesinde tartışılmaktadır (Kent, 2015: 12; Kalabalık, 2014: 201 vd.). Yine, imara aykırı yapıların dönem dönem çeşitli plan değişiklikleri ve af düzenlemeleriyle hukuka uygun hale getirilmeleri, özellikle belirli aşama kaydedilen işlerde iptal yatırımıyla karşı karşıya kalınması halinde önemli sıkıntılar doğurabilmektedir. 
Bugün için imar planlarının temel şehircilik ilke ve esaslarına uygun olup olmadığı, özellikle plansız şehirlerde ve deprem bölgelerinde önemli bir tartışma konusudur. Hatta, imar planına uygun ruhsatlı yapilarda oturumun mevcudiyeti, ileride mahkemece ya da idarece olası iptalleri zorlaştırmakta, buna rağmen yapılan iptallerde çeşitli mağduriyetler ortaya çıkabilmektedir. Dolayısıyla imar planları yapılırken azami özenin gösterilmesi, ileride doğacak yeni ihtiyaçlar çerçevesinde yapılacak değişikliklerin asgari seviyede kalmasına vesile olacak; idareler tarafından değişiklik ve iptal yapılmasına gerek bırakmayacaktır. Yine de değişiklik yapılması gerekiyorsa, kazanılmış haklara azami ölçüde saygı duyulması, kişilerin mağdur edilmemesine dikkat gösterilmelidir.

\section{SONUÇ}

İmar planlarının yapılması, değiştirilmesi gibi faaliyetlerde esas alınacak temel kanun, İmar Kanunu'dur. Buna göre planlar, üst ölçekten alt ölçeğe göre doğru hiyerarşik bir düzen içindedir ve bir üst ölçekteki plan, kendisinden sonraki sırada yer alan alt ölçekli plana esas teşkil etmektedir. Dolayısıyla, alt ölçekteki planların, üst ölçekteki planlara uygun bir biçimde, imar mevzuatına ve hukukun genel ilkelerine uygun şekilde hazırlanmış olmaları gerekmektedir. Planların hazırlanması aşamasında, gerekli tüm incelemeler ve araştırmaların titizlikle yapılması, imar mevzuatına uygunluğun sağlanması ve kamu yararının gerçekleştirilmesi için son derece elzemdir. Zira, imar planlarını yapmakla görevlendirilmiş bulunan yerel idare yahut Çevre ve Şehircilik Bakanlığı, sağlıklı ve düzenli bir şehirleşmenin gerçekleşmesiyle toplumun refah seviyesinin yükseltilmesini kendisine esas alarak faaliyet göstermelidir. Düzenleyici idari işlemler arasında bulunan imar planları, yetkide ve şekilde paralellik ilkesi çerçevesinde, yetkili ve görevli idarelerce yapılmalıdır. Çalışmamızda bu noktada esas alınan ilkelere işaret edilmiş, planların yapımına ve değiştirilmesi usullerine ayrıntılı bir biçimde yer verilmiştir. Bu bağlamda, plan yapım aşamaları detaylıca irdelenmiş ve ortaya çıkabilecek muhtemel sorunlar ve bunların ne şekilde çözüleceğine değinilmiştir. İmar hukukunun gelişim içerisinde olması ve ülkemizde de sık sık imar mevzuatının değiştirilmesi, yeknesaklığın tam olarak sağlanamaması gerekçeleriyle planların yapım aşamalarında yaşanan sıkıntılar ve bunların çözüm yolları gösterilmiştir.

Önceden belirlenmiş hedeflere ulaşılabilmesini temin için, planların mümkün olduğunca değiştirilmesine gerek kalmayacak şekilde hazırlanması gerekir. Bu sebeple planlama aşamasında hedefler doğru belirlenmeli, araştırma ve hazırlık aşamalarıyla veri toplanan dönem başta olmak üzere, tüm sürecin şeffaflık ve titizlikle yürütülmesine dikkat edilmelidir. Bu davranış biçimi, imar planları vasıtasıyla insanların devlete olan güvenini tazeleyecek ve hukuki belirlilik ilkesinin önemli görünüm biçimlerinden birisi olacaktır. Çalışmamızda da belirttiğimiz gibi, farklı etkenler sebebiyle planların güncelliğini yitirmesi yahut değiştirilmelerinin elzem hale gelmesi söz konusu olduğunda, sayı ve etki bakımından değişiklikler aza indirgenerek plana olan güvenin korunması gerekir. Plan değişikliğinde, şehircilik esaslarıyla planlamanın bütünlük ve ana kararlara uygunluk ilkeleri, kamu menfaatleri ve kazanılmış hak ilkesi dikkate alınmalıdır. Burada önemle ifade edilmelidir ki, İmar Kanunu, Mekansal Planlar Yapım Yönetmeliği ve diğer mevzuat hükümlerinde plan yapımı ve değişikliğine ilişkin yapılan farklı belirlemelerle mevzuatın sık değiştirilmesi, potansiyel uyuşmazlıklara zemin hazırlamaktadır. Bu itibarla, imar planı hakkında yetkisi olan tüm makamların çelişkileri giderilmiş bir mevzuat ve hukuka uygun davranması şarttır. 
Son olarak, planların ortadan kaldırılması usulleriyle alakalı olarak hem idarenin re'sen ortadan kaldırması şeklinde hem de ilgililerin başvurusu sonucunda idare mahkemeleri vasıtasıyla yapılabileceğine işaret edilmiştir. Plan yapımı veya değişikliği için iptal yoluna başvurabilecek kişiler, o bölgede yaşayan oturan ve diğer menfaat sahipleri olabilir. Menfaatin belirlenmesi çoğunlukla yargı kararlarıyla yapılmakta ve farklı kişi ve kurum/kuruluşların menfaatleri de kabul edilmektedir. İdareler tarafından plan değişikliği veya yeni plan yapılması suretiyle oluşturulan yeni planlar ile mahkemece iptal edilen planların yeniden düzenlenmesinde, kamu menfaatleri ve bölgesel ihtiyaçların en üst seviyede dikkate alınması elzemdir. İdarenin hem planların yapımı hem de değiştirilmesinde, idare hukukunun ilkelerine (yetki, şekil, sebep, konu, maksat) azami ölçüde uyması, yapılan işlemlerin mutlaka gerekçelerinin ortaya konması ve kamu nezdindeki güvenin korunması son derece önemlidir.

\section{KAYNAKÇA}

Bal, Burçak. (2010). İdari Bir İşlem Türü Olarak İmar Planı, Yayımlanmamış Yüksek Lisans Tezi. Ankara.

Bilgin, H. ve Sezer, Y. (2014). Açıklamah - İçtihatlı İmar Kanunu Uygulama Rehberi, 3. Baskı, Ankara: Seçkin Yayınevi.

Canbazoğlu, K. ve Ayaydın, D. (2011). "İmar Planlarının Yargısal Denetimi”, TBB Dergisi 2011(93), 239-281.

Çiçek, Kadir. (2016). İmar Plan Değişikliklerinin Usul ve Esasları. Yayımlanmamış Yüksek Lisans Tezi. İstanbul.

Çolak, Nusret İlker. (2010). İmar Hukuku. İstanbul: On İki Levha Yayıncilık.

Çolak, N. İ. ve Öngören G. (2014). İmar Hukuku. İstanbul: Öngören Hukuk Yayınları.

Davut, Ş. ve Coşkun, Ş. (2011). “İmar Planlarına Karşı Açılacak İptal Davalarında İdari Dava Açma Süresi”, İ̈̈HFM, LXIX (1-2), 1209-1242.

Demir, Aysel. (2009). Müge İmar Planı Değişikliklerinin Değerlendirilmesi Zeytinburnu Örneği, Yayımlanmamış Yüksek Lisans Tezi. İstanbul.

Ergen, Cafer. (2006). İmar Planları. Ankara: Seçkin Yayıncılık.

Ersoy, Melih. İmar Planı Değişiklikleri ve Yarg1 Denetimi. http://www.melihersoy.com/wpcontent/uploads/2012/04/plan-degisikligi1.pdf (Erişim: 09.10.2020)

Genç, Mustafa. (2015). İmar Hukuku. Ankara: Seçkin Yayıncılık.

Günday, Metin. (2003). İdare Hukuku. Ankara: İmaj Yayınevi.

Hanağası, Emel. (2009). Davada Menfaat. Ankara: Yetkin Yayınları.

Kalabalık, Halil. (2014). İmar Hukuku Dersleri, Ankara: Seçkin Yayıncılık.

Kara, Seyfettin. (2016). Danıştay Kararları Işı̆̆ı̆ıda İmar Planı Değişikliği, Ankara: Yetkin Yayınları.

Keleş, Ruşen. (2015). Kentleşme Politikası. Ankara: İmge Yayınevi. 
Kent, Bülent. (2015). “İmar Planlarının Değiştirilmesi, Plan Yapı ve Ruhsatlarının İptali ve Geri Alınmasının Kazanılmış Haklar Üzerindeki Etkileri", Sakarya Üniversitesi Hukuk Fakültesi Dergisi, 3 (1), 11-37.

Öz, Bayram. (2011). İdari İşlemin Bir Parçası Olarak İmar Planlarının Yargısal Denetimi, Yayımlanmamış Yüksek Lisans Tezi. İstanbul.

Sancakdar, Oğuz. (1996). Belediyenin İmar Planını Yapması-Değiştirmesi ve Íptal Davası, Ankara: Yetkin Yayınları.

Tekinsoy, A. (2008). “İmar Planlarının Hukuksal Niteliği, İmar Planı İptalinin Bu Plana Dayanılarak Verilmiş Ruhsatlar Üzerindeki Etkisi", Ankara Barosu Dergisi, 66(2), 4656.

Tunçer, Mehmet. Makro Planlamada Eşik Analizi ve SWOT, https://www.academia.edu/4171983/Makro_Planlamada_Eşik_analizi_ve_SWOT?aut $\mathrm{o}=$ download (Erişim: 15.10.2020)

Yaşar, Hasan N. (2008). İmar Hukuku. İstanbul: Filiz Kitabevi.

Yayla, Yıldızhan. (2010). İdare Hukuku. İstanbul: Beta Yayınevi.

Yıldız, Ferruh. (2012). Imar Bilgisi Planlama Uygulama Mevzuat. Ankara: Nobel Yayıncılık.

Yılmaz, Ejder. (2008). Hukuk Sözlüğ̈̈̈. Ankara: Yetkin Yayınları.

www.danistay.gov.tr (Erişim: 15.10.2020)

www.kazanci.com (Erişim: 12.10.2020) 